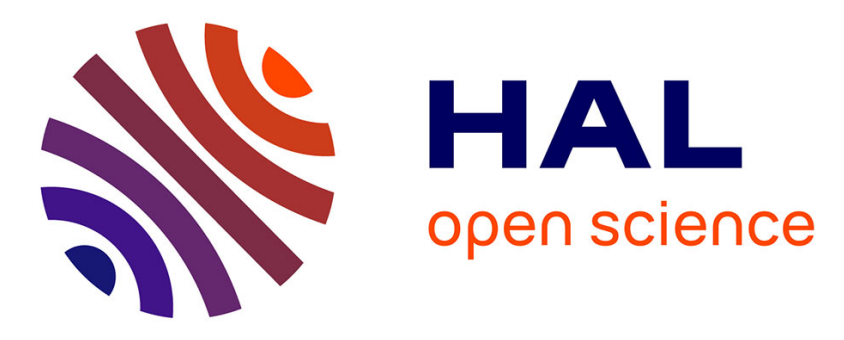

\title{
Oxygen Insertion Reactions within the One-Dimensional Channels of Phases Related-to FeSb2O4
}

\author{
Benjamin P. de Laune, Gregory J. Rees, Mariana J. Whitaker, Hien-Yoong
} Hah, Charles E. Johnson, Jacqueline A. Johnson, Dennis E. Brown, Matthew G. Tucker, Thomas C. Hansen, Frank J. Berry, et al.

\section{To cite this version:}

Benjamin P. de Laune, Gregory J. Rees, Mariana J. Whitaker, Hien-Yoong Hah, Charles E. Johnson, et al.. Oxygen Insertion Reactions within the One-Dimensional Channels of Phases Related-to FeSb2O4. Inorganic Chemistry, 2017, 56 (1), pp.594-607. 10.1021/acs.inorgchem.6b02466 . hal-01691857

\section{HAL Id: hal-01691857 https://hal.science/hal-01691857}

Submitted on 24 Jan 2018

HAL is a multi-disciplinary open access archive for the deposit and dissemination of scientific research documents, whether they are published or not. The documents may come from teaching and research institutions in France or abroad, or from public or private research centers.
L'archive ouverte pluridisciplinaire HAL, est destinée au dépôt et à la diffusion de documents scientifiques de niveau recherche, publiés ou non, émanant des établissements d'enseignement et de recherche français ou étrangers, des laboratoires publics ou privés. 


\section{Oxygen Insertion Reactions within the One-Dimensional Channels of Phases Related to $\mathrm{FeSb}_{2} \mathrm{O}_{4}$}

Benjamin P. de Laune, ${ }^{\#}$ Gregory J. Rees, ${ }^{\S}$ Mariana J. Whitaker, ${ }^{\#}$ Hien-Yoong Hah, ${ }^{\bigcirc, \perp}$ Charles E. Johnson, ${ }^{\bigcirc}$ Jacqueline A. Johnson, ${ }^{\bigcirc, \perp}$ Dennis E. Brown, ${ }^{\|}$Matthew G. Tucker, Thomas C. Hansen, ${ }^{\dagger}$ Frank J. Berry, John V. Hanna, ${ }^{\S}$ and Colin Greaves*,\# ${ }^{*}$

${ }^{\#}$ School of Chemistry, University of Birmingham, Birmingham B15 2TT, U.K.

${ }^{\S}$ Department of Physics, University of Warwick, Coventry CV4 7AL, U.K.

${ }^{\circ}$ Center for Laser Applications and ${ }^{\perp}$ Department of Mechanical, Aeronautical and Biomedical Engineering, University of Tennessee Space Institute, Tullahoma, Tennessee 37388, United States

"Department of Physics, Northern Illinois University, DeKalb, Illinois 60115, United States

${ }^{\ddagger}$ Oak Ridge National Laboratory, Oak Ridge, Tennessee 37831, United States

${ }^{\dagger}$ Institut Laue Langevin, BP 156, F-38042 Grenoble 9, France

Supporting Information

ABSTRACT: The structure of the mineral schafarzikite, $\mathrm{FeSb}_{2} \mathrm{O}_{4}$, has one-dimensional channels with walls comprising $\mathrm{Sb}^{3+}$ cations; the channels are separated by edge-linked $\mathrm{FeO}_{6}$ octahedra that form infinite chains parallel to the channels. Although this structure provides interest with respect to the magnetic and electrical properties associated with the chains and the possibility of chemistry that could occur within the channels, materials in this structural class have received very little attention. Here we show, for the first time, that heating selected phases in oxygen-rich atmospheres can result in relatively large oxygen uptakes (up to $\sim 2 \%$ by mass) at low temperatures (ca. $350{ }^{\circ} \mathrm{C}$ ) while retaining the parent structure. Using a variety of structural

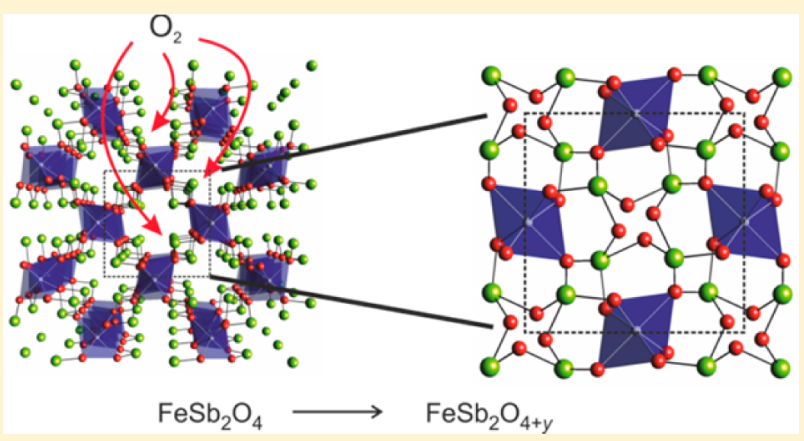
and spectroscopic techniques, it is shown that oxygen is inserted into the channels to provide a structure with the potential to show high one-dimensional oxide ion conductivity. This is the first report of oxygen-excess phases derived from this structure. The oxygen insertion is accompanied not only by oxidation of $\mathrm{Fe}^{2+}$ to $\mathrm{Fe}^{3+}$ within the octahedral chains but also $\mathrm{Sb}^{3+}$ to $\mathrm{Sb}^{5+}$ in the channel walls. The formation of a defect cluster comprising one 5-coordinate $\mathrm{Sb}^{5+}$ ion (which is very rare in an oxide environment), two interstitial $\mathrm{O}^{2-}$ ions, and two 4-coordinate $\mathrm{Sb}^{3+}$ ions is suggested and is consistent with all experimental observations. To the best of our knowledge, this is the first example of an oxidation process where the local energetics of the product dictate that simultaneous oxidation of two different cations must occur. This reaction, together with a wide range of cation substitutions that are possible on the transition metal sites, presents opportunities to explore the schafarzikite structure more extensively for a range of catalytic and electrocatalytic applications.

\section{INTRODUCTION}

The tetragonal mineral schafarzikite $\left(\mathrm{FeSb}_{2} \mathrm{O}_{4} ; \mathrm{P}_{2} / \mathrm{mbc} a=\right.$ $8.62 \AA c=5.91 \AA)^{1}$ is of significant interest because of its unusual one-dimensional (1-D) structural characteristics and its ability to display a high degree of compositional flexibility. The structure is related to that of rutile, $\mathrm{TiO}_{2}$, but neighboring chains of edge-shared transition metal octahedra, $\mathrm{MO}_{6}$, along [001] are now separated: in contrast to the rutile structure, the chains do not share anions with adjacent chains but are connected through $\mathrm{O}-\mathrm{Sb}-\mathrm{O}$ linkages (Figure 1). In $\mathrm{FeSb}_{2} \mathrm{O}_{4}$, the chains of octahedra contain $\mathrm{Fe}^{2+}$ (A-site), and $\mathrm{Sb}^{3+}$ (B-site) provides the link. The $\mathrm{B}$-site has trigonal pyramidal coordination, $\mathrm{SbO}_{3}$, which can also be regarded as pseudotetrahedral, $\mathrm{SbO}_{3} \mathrm{E}$, by including the stereochemically active lone pair of electrons (E). These electron pairs appear crucial for stabilizing the second key structural feature: channels that exist along [001], parallel to the chains of octahedra. $\mathrm{Sb}^{3+}$ ions form the channel walls and their lone pairs, E, are directed into the channels.

The structure can accommodate a range of cations on both the A-site ${ }^{2-7}$ and B-site. ${ }^{8-10}$ Partial substitution of aliovalent cations at the B-site in $\mathrm{MSb}_{2} \mathrm{O}_{4}$, e.g., $\mathrm{Pb}^{2+}$ for $\mathrm{Sb}^{3+}$, has previously been examined with the expectation that oxidation of $\mathrm{M}^{2+}$ to $\mathrm{M}^{3+}$ will provide charge balance and allow control over electronic and magnetic properties. Although this strategy

Received: October 12, 2016

Published: December 15, 2016 

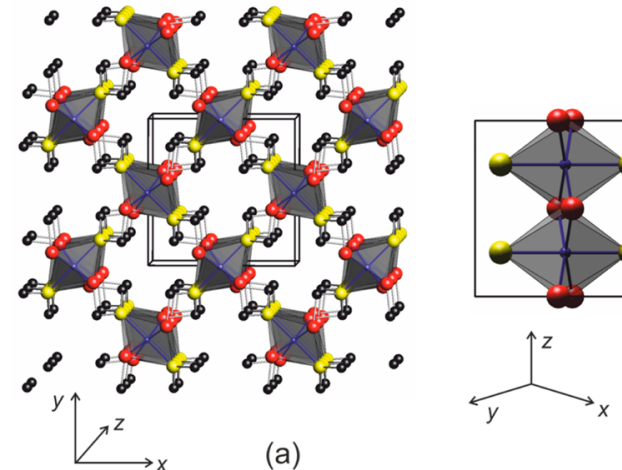

(a)

Figure 1. Schafarzikite structure viewed (a) approximately along [001] showing the empty channels and (b) along [110]. Elements are represented as colored spheres: $\mathrm{Fe}^{2+}$ (A site; blue), $\mathrm{Sb}^{3+}$ (B site; black), and $\mathrm{O}^{2-}$ in the $\mathrm{O} 2$, equatorial, (red) and $\mathrm{O} 1$, apical, (yellow) positions. $\mathrm{FeO}_{6}$ octahedra are gray.

may result in simultaneous or preferential oxidation of $\mathrm{Sb}^{3+}$, resulting in mixed phase products, ${ }^{11,12}$ we have recently achieved complete success for $\mathrm{M}=\mathrm{Fe}$, where controlled oxidation of $\mathrm{Fe}^{2+}$ to $\mathrm{Fe}^{3+}$ has been achieved. ${ }^{13}$

Examination of the physical properties of materials related to $\mathrm{FeSb}_{2} \mathrm{O}_{4}$ has, to date, been largely limited to the magnetic properties of phases containing transition metal ions, ${ }^{7,12-15}$ for which the link between composition, structure, and magnetic order is now well understood. ${ }^{7,14}$ A complex interplay between three magnetic exchange pathways determines the magnetic ground state: intrachain direct $\mathrm{M}-\mathrm{M}$ exchange, $90^{\circ}$ superexchange along a chain, and a weaker but significant interchain $\mathrm{M}-\mathrm{O}-\mathrm{Sb}-\mathrm{O}-\mathrm{M}$ exchange. All systems are antiferromagnetic except for $\mathrm{CuAs}_{2} \mathrm{O}_{4}$ which is ferromagnetic at low temperatures. ${ }^{16}$ The chemical reactivity of the materials has received even less attention. This is surprising since the structural channels display a feature which, to the best of our knowledge, is unique: cations $\left(\mathrm{Sb}^{3+}\right.$ ions) form the channel walls, whereas channels in oxide materials normally have walls of $\mathrm{O}^{2-}$ ions such that the cavities are suitable hosts for cationic species. Channel walls in aluminosilicates, for example, are $\mathrm{O}^{2-}$ ions from $\mathrm{Al} / \mathrm{SiO}_{4}$ tetrahedra. In schafarzikites, therefore, we could anticipate the chemical insertion of anions rather than cations, and here we demonstrate the first example of such a reaction where a unique oxidation mechanism occurs for phases with Asites containing some $\mathrm{Fe}^{2+}$ ions and $\mathrm{B}$-sites containing some $\mathrm{Sb}^{3+}$ ions. Oxygen insertion into the channels occurs at low temperatures (for solid state reactions) to provide new metastable phases in which simultaneous oxidation of both $\mathrm{Fe}^{2+}$ and $\mathrm{Sb}^{3+}$ has occurred; the proposed mechanism provides suitable chemical environments for both the $\mathrm{Sb}^{3+}$ and $\mathrm{Sb}^{5+}$ cations that bond to the interstitial $\mathrm{O}^{2-}$ ions.

The low-temperature oxidation mechanism discussed here is thought to be unique and suggests high oxygen and/or oxide ion mobility within the channels. It is pertinent to note that low-dimensional structures containing partially filled oxide ion sites have recently gained interest for energy materials since they can provide an interstitial mechanism for oxide ion migration rather than the normal vacancy driven mechanism that occurs, for example, in the fluorite solid electrolyte YSZ, $\mathrm{Zr}_{1-x} \mathrm{Y}_{x} \mathrm{O}_{2-x / 2} .{ }^{17}$ This interest also extends to cathode materials where mixed conductivity is required. A recent example is the study of the oxygen excess, mixed conducting, RuddlesdenPopper phases $(\mathrm{La}, \mathrm{Pr})_{2}(\mathrm{Ni}, \mathrm{Co}) \mathrm{O}_{4+\delta} 18$ where the excess oxygen

enters the structure between two adjacent rocksalt-related layers and can coordinate tetrahedrally to lanthanide ions. In this respect, materials with channels containing highly mobile interstitial oxide ions would be of special interest. Given that a range of transition metals can occupy the chains of octahedra, the focus of this study is therefore also highly relevant to the search for new catalysts and electrocatalysts.

\section{EXPERIMENTAL SECTION}

A variety of compounds with the schafarzikite structure were synthesized by heating intimately ground stoichiometric mixtures of dried metal oxides and metals in evacuated, sealed quartz tubes at $600-750{ }^{\circ} \mathrm{C}$ for $6 \mathrm{~h}$ periods with intermittent grinding. Alumina inserts were used to prevent reaction with the quartz. Critical to the results presented in this paper is the amount of $\mathrm{Fe}^{2+}$ per formula unit (pfu); this was controlled by either isovalent cation substitutions at the A-site or aliovalent substitution of $\mathrm{Pb}^{2+}$ for $\mathrm{Sb}^{3+}$ at the $\mathrm{B}$-site, and compositions with particular relevance to this paper are given in Table 1. The compositions reported here were chosen to provide important

Table 1. Important Phase Compositions and Their $\mathrm{Fe}^{2+}$ Content

\begin{tabular}{lc}
\multicolumn{1}{c}{ composition } & amount of $\mathrm{Fe}^{2+}$ per formula unit \\
$\mathrm{Co}_{0.75} \mathrm{Fe}_{0.25} \mathrm{Sb}_{2} \mathrm{O}_{4}$ & 0.25 \\
$\mathrm{Mg}_{0.75} \mathrm{Fe}_{0.25} \mathrm{Sb}_{2} \mathrm{O}_{4}$ & 0.25 \\
$\mathrm{FeSb}_{1.25} \mathrm{~Pb}_{0.75} \mathrm{O}_{4}$ & $0.25 \mathrm{Fe}^{2+}\left(+0.75 \mathrm{Fe}^{3+}\right)$ \\
$\mathrm{Co}_{0.25} \mathrm{Fe}_{0.75} \mathrm{Sb}_{1.75} \mathrm{~Pb}_{0.25} \mathrm{O}_{4}$ & $0.50 \mathrm{Fe}^{2+}\left(+0.25 \mathrm{Fe}^{3+}\right)$
\end{tabular}

control of the $\mathrm{Fe}^{2+}$ content (given in Table 1); this was kept quite low to avoid large oxygen absorption, which was found to result in broadened diffraction peaks. Both $\mathrm{Mg}^{2+}$ and $\mathrm{Co}^{2+}$ substitutions for $\mathrm{Fe}^{2+}$ were used to provide substantial differences to electronic conductivity within the chains of octahedra. The partial substitution of $\mathrm{Pb}^{2+}$ for $\mathrm{Sb}^{3+}$ not only reduced the $\mathrm{Fe}^{2+}$ content but also enhanced the high temperature stability which was important for revealing that the oxidation involved two discrete steps. Oxidised phases were created by heating samples in air or oxygen. For ${ }^{17} \mathrm{O}$ NMR analysis, samples of $\mathrm{MgSb}_{2} \mathrm{O}_{4}$ and $\mathrm{Sb}_{2} \mathrm{O}_{3}$ were exchanged with ${ }^{17} \mathrm{O}$-enriched $\mathrm{H}_{2} \mathrm{O}$ hydrothermally, and $\mathrm{FeSb}_{2} \mathrm{O}_{4}$-related phases were exchanged with ${ }^{17} \mathrm{O}$-enriched oxygen gas $\left(75 \%\right.$ enrichment) at $350{ }^{\circ} \mathrm{C}$ for times of 12-66 min depending on the observed rate of oxygen absorption. Full experimental details are provided in Supporting Information.

\section{RESULTS}

3.1. Thermogravimetric Analysis (TGA). Mass changes for three representative samples heated in oxygen gas are shown in Figure 2. All are unstable above $600{ }^{\circ} \mathrm{C}$ and form

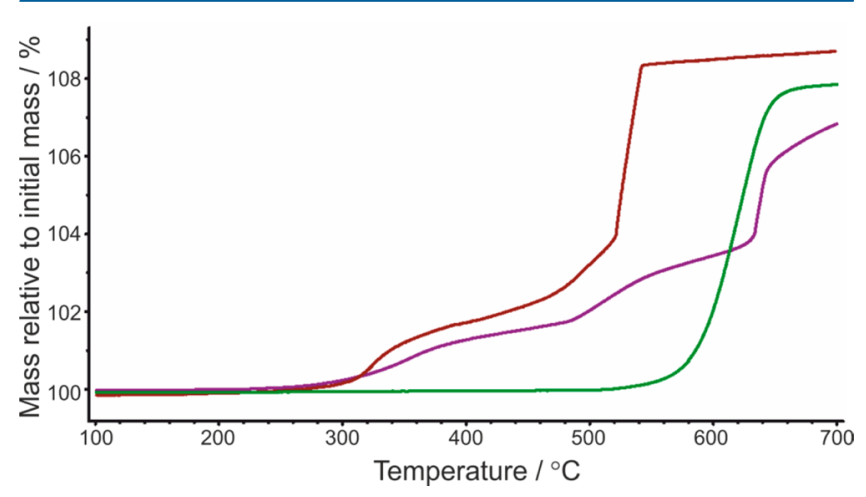

Figure 2. TGA plots for $\mathrm{CoSb}_{2} \mathrm{O}_{4}$ (green), $\mathrm{Mg}_{0.25} \mathrm{Fe}_{0.75} \mathrm{Sb}_{2} \mathrm{O}_{4}$ (brown), $\mathrm{Co}_{0.25} \mathrm{Fe}_{0.75} \mathrm{Sb}_{1.75} \mathrm{~Pb}_{0.25} \mathrm{O}_{4}$ (purple) heated in an $\mathrm{O}_{2}$ atmosphere at $10{ }^{\circ} \mathrm{C} \mathrm{min}^{-1}$ to $800{ }^{\circ} \mathrm{C}$. 
$\mathrm{Sb}^{5+}$-containing products; $\mathrm{CoSb}_{2} \mathrm{O}_{4}$, for example, simply forms $\mathrm{CoSb}_{2} \mathrm{O}_{6}$ with a mass increase of ca. $8 \%$ (expected $8.7 \%$ ). However, a low-temperature plateau is also observed centered at $\sim 400{ }^{\circ} \mathrm{C}$ for all samples containing $\mathrm{Fe}^{2+}$ ions. Indeed, the sample $\mathrm{Co}_{0.25} \mathrm{Fe}_{0.75} \mathrm{Sb}_{1.75} \mathrm{~Pb}_{0.25} \mathrm{O}_{4}$ shows strong evidence that an additional process occurs at higher temperatures to provide a second plateau centered at $\sim 550{ }^{\circ} \mathrm{C}$. It should be emphasized that the low-temperature plateau is not observed for $\mathrm{CoSb}_{2} \mathrm{O}_{4}$ and is observed only in samples containing $\mathrm{Fe}^{2+}$; moreover, the mass increase at this plateau is related to the amount of $\mathrm{Fe}^{2+}$ in the sample (see Figure 3). It is assumed that for all materials

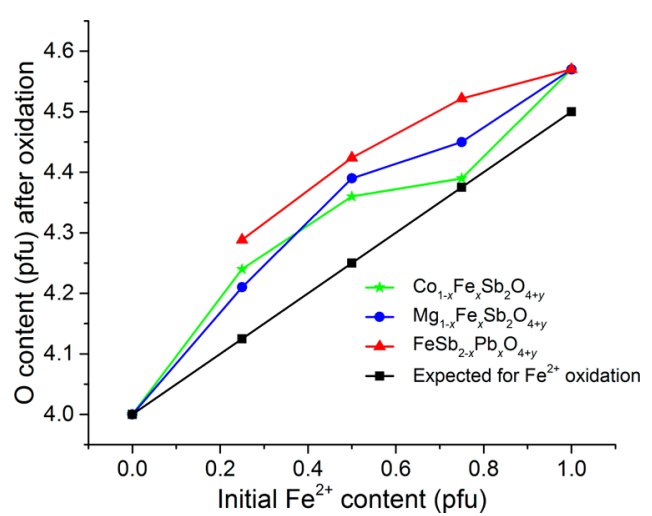

Figure 3. Increase in oxygen content per formula unit (pfu) as a function of initial $\mathrm{Fe}^{2+}$ content pfu from TGA data for the three series indicated. The results are compared to those expected assuming only oxidation of $\mathrm{Fe}^{2+}$ to $\mathrm{Fe}^{3+}$.

investigated, the substitution of $\mathrm{Pb}^{2+}$ for $\mathrm{Sb}^{3+}$ is balanced only by oxidation of $\mathrm{Fe}^{2+}$ to $\mathrm{Fe}^{3+}$ in accordance with previous studies. ${ }^{13}$ The clear link between the mass increase and the $\mathrm{Fe}^{2+}$ content of the sample may, at first sight, suggest that for every $\mathrm{O}^{2-}$ ion absorbed, charge balance is satisfied by oxidation of $2 \mathrm{Fe}^{2+}$ to $2 \mathrm{Fe}^{3+}$. However, a critical feature for all samples exhibiting the low temperature plateau is that the amount of oxygen absorbed is, in fact, significantly higher than that expected for oxidation of all $\mathrm{Fe}^{2+}$ to $\mathrm{Fe}^{3+}$. This is clear in Figure 3 which also shows that the oxygen uptake at low $\mathrm{Fe}^{2+}$ contents (up to $0.50 \mathrm{Fe}^{2+} \mathrm{pfu}$ ) is, in fact, approximately twice that expected. Two possibilities were considered as plausible explanations: either other cations, in addition to $\mathrm{Fe}^{2+}$, are oxidized (or higher oxidation states of $\mathrm{Fe}$ are formed), or oxygen enters as peroxide ions, $\mathrm{O}_{2}^{2-}$, rather than $\mathrm{O}^{2-}$ ions. A structural study was therefore conducted to determine the precise nature of the structural changes that occur during oxidation.

3.2. Structure of $\mathrm{FeSb}_{1.25} \mathrm{~Pb}_{0.75} \mathrm{O}_{4+y}$. Powder X-ray diffraction (PXRD) analysis of samples obtained by cooling from the low temperature plateaus on the TGA plots revealed that the basic structure had been retained (space group $P 4_{2} /$ $m b c$ ) but with changes to the unit cell dimensions: a reduction in $a$ and increase in $c$. This is similar to that observed when $\mathrm{Pb}^{2+}$ is substituted for $\mathrm{Sb}^{3+}$ in $\mathrm{FeSb}_{2} \mathrm{O}_{4}$, where oxidation of Asite cations within the chains of octahedra results in increased intrachain $\mathrm{Fe}-\mathrm{Fe}$ repulsions and consequently an expansion of c. For samples with large $\mathrm{Fe}^{2+}$ contents, e.g., $\mathrm{FeSb}_{2} \mathrm{O}_{4}$, the large amount of oxygen incorporation resulted in a degree of structure degradation; structure determination was therefore focused on the oxidation product of $\mathrm{FeSb}_{1.25} \mathrm{~Pb}_{0.75} \mathrm{O}_{4}$, which initially contained $25 \% \mathrm{Fe}^{2+}$ and $75 \% \mathrm{Fe}^{3+} \cdot{ }^{13}$ Figure 3 shows that a significant oxygen uptake occurs for this composition, and a sample for NPD study ( $\sim \mathrm{g})$ was prepared by heating in air at $400{ }^{\circ} \mathrm{C}$ for $12 \mathrm{~min}$. TGA suggested that the final composition was $\mathrm{FeSb}_{1.25} \mathrm{~Pb}_{0.75} \mathrm{O}_{4.29(1)}$ compared to $\mathrm{FeS}$ $\mathrm{b}_{1.75} \mathrm{~Pb}_{0.25} \mathrm{O}_{4.125}$, which is predicted if oxygen insertion as $\mathrm{O}^{2-}$ ions is balanced only by oxidation of $\mathrm{Fe}^{2+}$ to $\mathrm{Fe}^{3+}$.

NPD data (HRPT at PSI, $300 \mathrm{~K}, \lambda=1.8852 \AA$ ) were collected on $\mathrm{FeSb}_{1.25} \mathrm{~Pb}_{0.75} \mathrm{O}_{4.29(1)}$ at ambient temperature. Because of the relatively small change in composition, structure refinement based on the structure of the stoichiometric, unoxidiszed material gave a good fit to the data. However, difference Fourier maps suggested additional scattering density within the channels, as shown in Figure 4; inclusion of an oxide

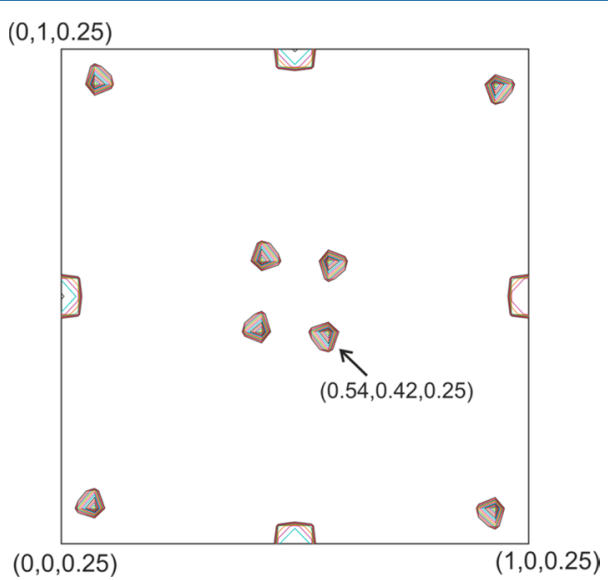

Figure 4. Difference Fourier map for $\mathrm{FeSb}_{1.25} \mathrm{~Pb}_{0.75} \mathrm{O}_{4.24}$ showing additional neutron scattering near the center of the channel running along [001] and located at $(0,0, z)$; see Figure 1 . The position corresponding to the $\mathrm{O} 3$ site of Table 2 is marked.

ion into the refinement at the suggested position resulted in a small, but statistically significant, improvement to the fit $\left(\chi^{2}\right.$ decreased from 2.6 to 2.2 ). The profiles for the refinement are given in Figure 5, and the refined structural parameters are given in Table 2 where $\mathrm{O} 3$ represents the incorporated interstitial oxygen, $\mathrm{O} 1$ the apical and $\mathrm{O} 2$ the equatorial positions (see Figure 1). The disorder, from both the mixed $\mathrm{Sb} / \mathrm{Pb}$ on the $8 \mathrm{~h}$-site and the interstitial oxygen, resulted in

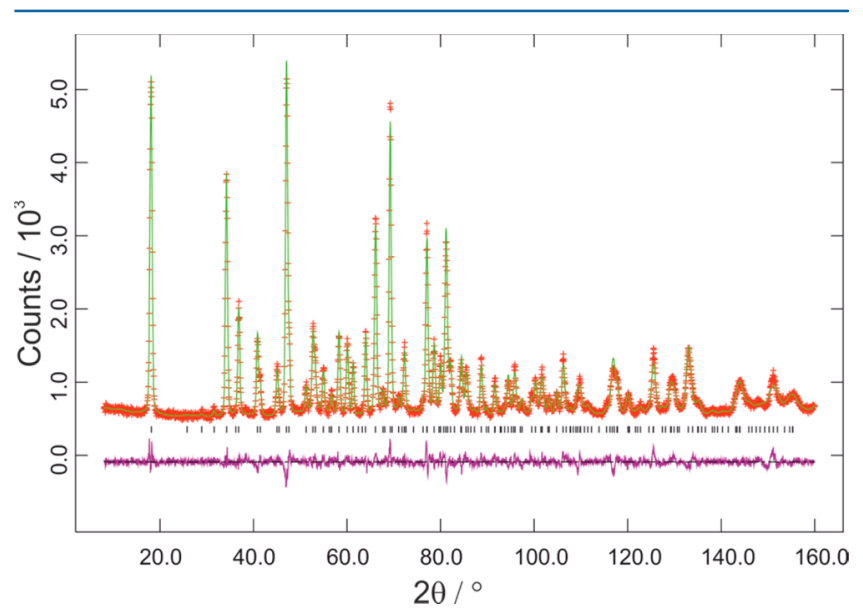

Figure 5. Rietveld refinement profiles for $\mathrm{FeSb}_{1.25} \mathrm{~Pb}_{0.75} \mathrm{O}_{4.24}$ showing raw data (red crosses), fitted profile (green) and difference profile (mauve). Reflection positions are marked as vertical bars. 
Table 2. Structural Parameters for $\mathrm{FeSb}_{1.25} \mathrm{~Pb}_{0.75} \mathrm{O}_{4+y}$ from NPD Data ${ }^{a}$

\begin{tabular}{lclllll} 
atom & position & \multicolumn{1}{c}{$x$} & \multicolumn{1}{c}{$y$} & \multicolumn{1}{c}{$z$} & $100 \times U_{\text {iso }}\left(\AA^{2}\right)$ & occupancy \\
$\mathrm{Fe}$ & $4 \mathrm{~d}$ & 0.0 & 0.5 & 0.25 & $2.19(6)$ & 1.0 \\
$\mathrm{Sb} / \mathrm{Pb}$ & $8 \mathrm{~h}$ & $0.1542(3)$ & $0.1557(3)$ & 0.0 & $2.82(6)$ & $0.625 / 0.375$ \\
$\mathrm{O} 1$ & $8 \mathrm{~g}$ & $0.6701(2)$ & $0.1701(2)$ & 0.25 & $3.90^{a}$ & 1.0 \\
$\mathrm{O} 2$ & $8 \mathrm{~h}$ & $0.0981(3)$ & $0.6278(3)$ & 0.0 & $2.64(8)$ & 1.0 \\
$\mathrm{O} 3$ & $16 \mathrm{i}$ & $0.540(5)$ & $0.417(3)$ & $0.254(7)$ & $3(1)$ & $0.059(4)$
\end{tabular}

${ }^{a}$ Anisotropic parameters $\left(\right.$ all $\left.\times 100 / \AA^{2}\right): \mathrm{U}_{11} 4.5(1), \mathrm{U}_{22} 4.5(1), \mathrm{U}_{33} 2.7(2) ; \mathrm{U}_{12}-2.4(1) . \mathrm{U}_{13}-0.8(1) \mathrm{U}_{23} 0.8(1) . P 4_{2} / m b c ; a=8.4063(3) \AA, b=$ 8.4063(3) $\AA, c=6.0443(3) \AA . \chi^{2}=2.24 ; R_{\mathrm{wp}}=0.051$.

high displacement parameters and significantly anisotropic displacement parameters for $\mathrm{O} 1$. The $\mathrm{Sb} / \mathrm{Pb}$ site occupancy was constrained to that weighed out. The refined composition, $\mathrm{FeSb}_{1.25} \mathrm{~Pb}_{0.75} \mathrm{O}_{4.24(1)}$, is in good agreement with the TGA value of $\mathrm{FeSb}_{1.25} \mathrm{~Pb}_{0.75} \mathrm{O}_{4.29(1)}$. The refined structure is shown in Figure 6, and some bond distances and bond valence sums

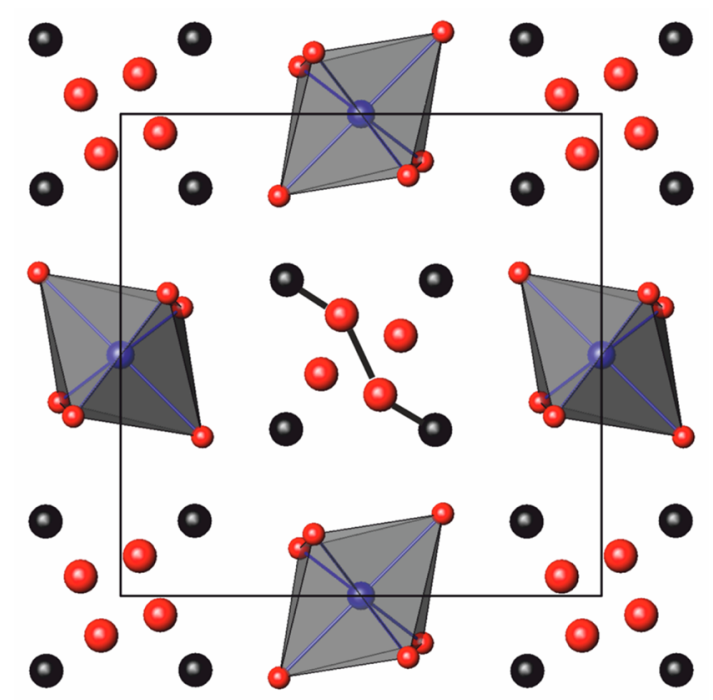

Figure 6. Refined structure of $\mathrm{FeSb}_{1.25} \mathrm{~Pb}_{0.75} \mathrm{O}_{4.24}$ highlighting the interstitial oxygen positions. All $\mathrm{O}$ are red, $\mathrm{Sb} / \mathrm{Pb}$ black, and $\mathrm{Fe}$ blue. A possible $\mathrm{O}-\mathrm{O}$ linkage $(\mathrm{O}-\mathrm{O} 1.54(5) \AA)$ is shown.

Table 3. Selected Bond Distances and Bond Valence Sums (Using the $r_{\mathrm{o}}$ Parameter for $\mathrm{Fe}^{3+}$ ) ${ }^{19}$ for $\mathrm{FeSb}_{1.25} \mathrm{~Pb}_{0.75} \mathrm{O}_{4+y}$

\begin{tabular}{lll}
\multicolumn{2}{c}{ bond distances $/ \AA$} & BVS \\
$\mathrm{Fe}-\mathrm{O} 1$ & $2.023(3)[\times 2]$ & 2.91 \\
$\mathrm{Fe}-\mathrm{O} 2$ & $2.029(2)[\times 4]$ & \\
$\mathrm{Sb} / \mathrm{Pb}-\mathrm{O} 1$ & $2.108(2)$ & \\
$\mathrm{Sb} / \mathrm{Pb}-\mathrm{O} 2$ & $2.095(4)[\times 2]$ & \\
$\mathrm{Sb} / \mathrm{Pb}-\mathrm{O} 3$ & $1.91(4), 2.30(5)$ & \\
$\mathrm{O} 3-\mathrm{O} 3$ & $1.09(3), 1.54(5)$ &
\end{tabular}

$(\mathrm{BVS})^{19}$ are given in Table 3. The shortest O3-O3 distances are 1.09(3) $\AA$ and 1.54(5) $\AA$, the latter being across the center of the channel as shown in Figure 6. Although these distances are too short for fully occupied sites, it should be noted that only $6 \%$ of the 16i-sites are actually occupied, so the model is entirely satisfactory for such an average structure. Table 3 gives the BVS for $\mathrm{Fe}$ (2.91) based on the $r_{\mathrm{o}}$ parameter for $\mathrm{Fe}^{3+}$, 1.759. ${ }^{19}$ This methodology has previously been found to yield excellent agreement between the Fe BVS and the Fe oxidation state for $\mathrm{FeSb}_{1-x} \mathrm{~Pb}_{x} \mathrm{O}_{4}$ with $x>0.4 .{ }^{13}$ For the $\mathrm{Fe}$ oxidation states of $2.45+, 2.50+$, and $2.70+$, the bond distances in ref 13 give BVS values of 2.54, 2.54, and 2.64. The BVS of 2.91 (Table 3 ) therefore provides strong evidence that the oxygen incorporation has resulted in complete oxidation of the $\mathrm{Fe}^{2+}$ present to $\mathrm{Fe}^{3+}$. However, the increase in oxygen content determined by the $\mathrm{O} 3$ occupancy is approximately twice that expected for a model in which insertion of $\mathrm{O}^{2-}$ ions is accompanied by oxidation of all $\mathrm{Fe}^{2+}$ to $\mathrm{Fe}^{3+}$. The $\mathrm{O} 3-\mathrm{O} 3$ separation of $1.54 \AA$ across the center of the channel is therefore of particular interest since it is similar to the $\mathrm{O}-\mathrm{O}$ separation in simple peroxides, e.g., $1.49 \AA$ in $\mathrm{Na}_{2} \mathrm{O}_{2}{ }^{20}$ The existence of peroxide (or even superoxide) links within the structure could explain why the observed mass increase is higher than that expected for simple oxidation of $\mathrm{Fe}^{2+}$ to $\mathrm{Fe}^{3+}$. A possible $\mathrm{O}-\mathrm{O}$ linkage is marked in Figure 6, where the $\mathrm{O} 3$ species are bonded to $\mathrm{Sb} / \mathrm{Pb}$ at a distance of 1.91(4) $\AA$ (Table 3).

3.3. Structural Changes during Oxidation. In order to obtain more detailed information on the structural changes occurring during the oxidation, and hence the mechanism involved, an in situ NPD study was conducted (D20 at ILL, Grenoble, $\lambda=1.5430 \AA$ ). The sample chosen for investigation was $\mathrm{Co}_{0.25} \mathrm{Fe}_{0.75} \mathrm{Sb}_{1.75} \mathrm{~Pb}_{0.25} \mathrm{O}_{4}$ since it has a high final decomposition temperature and a double plateau at low temperatures (Figure 2). Essential experimental details are given in Supporting Information for the oxidation under flowing oxygen with structural data collected up to $500{ }^{\circ} \mathrm{C}$. Initially, data were collected for $5 \mathrm{~min}\left(5{ }^{\circ} \mathrm{C}\right)$ intervals up to $350{ }^{\circ} \mathrm{C}$, conditions which were expected to yield a composition on the first low temperature plateau. Data were then collected for several extended periods $(15 \mathrm{~min})$ at $350{ }^{\circ} \mathrm{C}$ before temperature ramping was continued up to $500{ }^{\circ} \mathrm{C}$. To minimize the effects of correlation between the $\mathrm{O} 3$ site occupancy and its isotropic displacement parameter (IDP), the IDPs for $\mathrm{O} 1, \mathrm{O} 2$, and $\mathrm{O} 3$ were constrained to be equal; in addition, $\mathrm{Fe} / \mathrm{Co}$ site occupancy was constrained to $0.75 / 0.25$, i.e., as weighed out. Typical raw neutron diffraction data (corresponding to $320^{\circ} \mathrm{C}$ ) are shown in Figure $7 \mathrm{a}, \mathrm{b}$, and the profiles corresponding to the final refinement for this temperature are shown in Figure $7 \mathrm{c}$. Changes to important structural parameters are shown in Figure 8.

Occupancy of the interstitial oxygen site, $\mathrm{O} 3$, increased with temperature $(\mathrm{T})$ primarily in the range $200{ }^{\circ} \mathrm{C}<\mathrm{T}<350{ }^{\circ} \mathrm{C}$ (Figure 8a). On reaching $350{ }^{\circ} \mathrm{C}$, the $\mathrm{O} 3$ occupancy corresponds to an oxygen content of 4.40(2), in good agreement with the TGA value (Figure 2) of 4.36 at the midpoint of the plateau. However, full oxidation of $\mathrm{Fe}^{2+}$ to $\mathrm{Fe}^{3+}$ can account for an oxygen content of only 4.25 pfu. The small discontinuity in the data at $350{ }^{\circ} \mathrm{C}$ is a consequence of the isothermal measurements that were taken at this temperature. Figure $8 \mathrm{a}$ shows further increase in the $\mathrm{O} 3$ site occupancy 

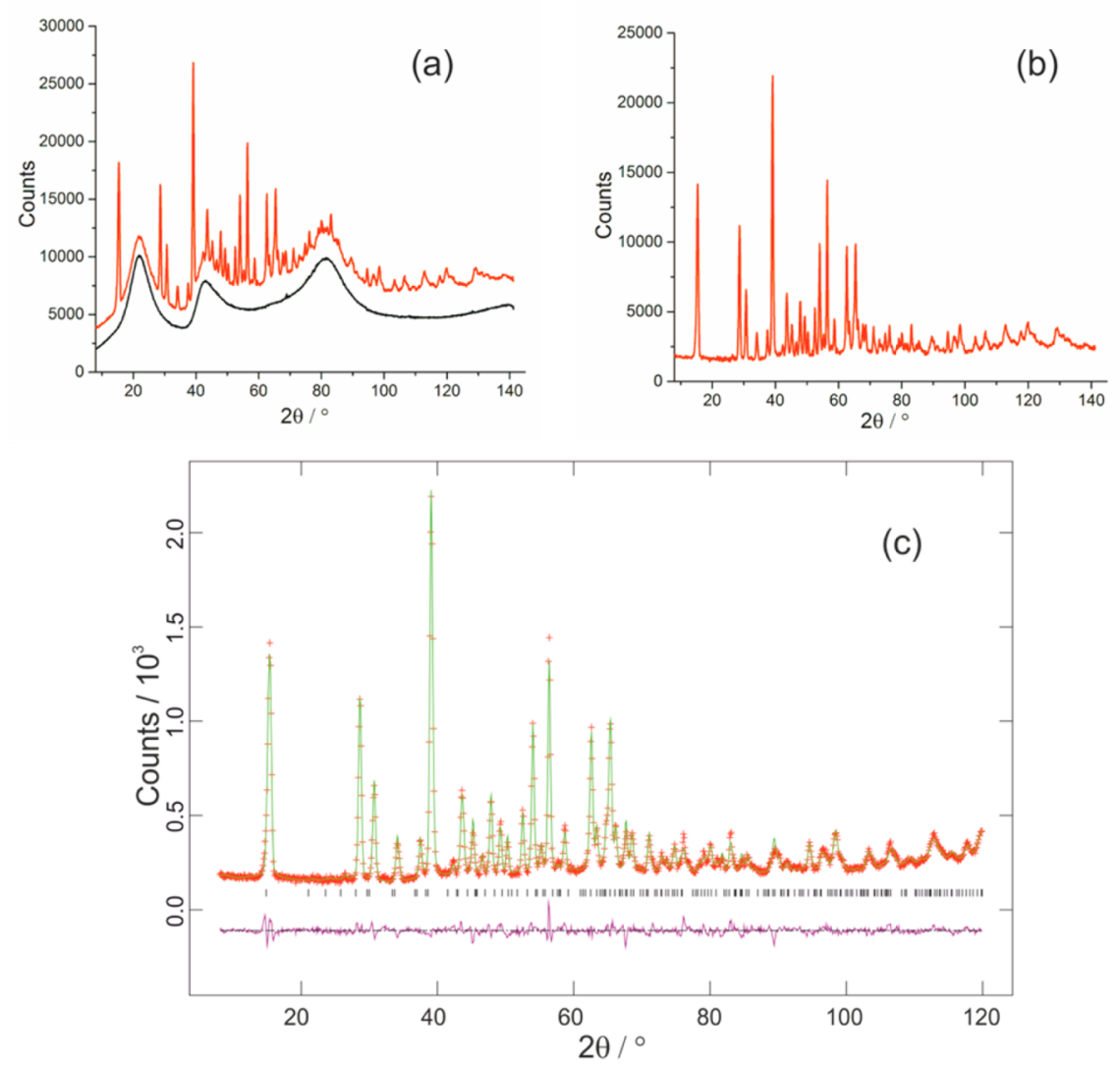

Figure 7. In situ NPD data for the oxidation of $\mathrm{Co}_{0.25} \mathrm{Fe}_{0.75} \mathrm{Sb}_{1.75} \mathrm{~Pb}_{0.25} \mathrm{O}_{4}$. (a) The raw data at $320{ }^{\circ} \mathrm{C}$ (red) and background (black) from an empty quartz tube at $300{ }^{\circ} \mathrm{C}$. (b) The corrected raw data after background subtraction. (c) Rietveld refinement profiles showing raw data (red crosses), fitted profile (green), and difference profile (mauve); reflection positions are marked as vertical bars.

between 350 and $500{ }^{\circ} \mathrm{C}$, but the slope for the uptake is reduced in this higher temperature region. It is important to note that all structural changes recorded in Figure 8 show a distinct discontinuity at approximately $350{ }^{\circ} \mathrm{C}$, which suggests a change in the oxidation mechanism at about this temperature. This was confirmed by other techniques, and details are presented later (sections 3.6 and 4).

Figure $8 \mathrm{~b}, \mathrm{c}$ shows changes to the unit cell parameters during the main oxidation $\left(200{ }^{\circ} \mathrm{C}<T<350{ }^{\circ} \mathrm{C}\right)$ : $a$ decreases, $c$ increases, and the volume decreases. This behavior is very similar to that observed for increasing $x$ in $\mathrm{FeSb}_{2-x} \mathrm{~Pb}_{x} \mathrm{O}_{4}$ where the increase in $c$ was attributed to enhanced cation-cation repulsion within the chains of octahedra resulting from the oxidation of $\mathrm{Fe}^{2+}$ to $\mathrm{Fe}^{3+13}$. For $\mathrm{T}>350{ }^{\circ} \mathrm{C}$, some oxidation continues (Figure 8a), but the main changes to the unit cell appear to be thermal in nature and the volume increases with temperature. These data support the importance of oxidation of $\mathrm{Fe}^{2+}$ to $\mathrm{Fe}^{3+}$ at temperatures up to $350{ }^{\circ} \mathrm{C}$. Confirmation is provided by the decrease in the average $\mathrm{Fe} / \mathrm{Co}-\mathrm{O}$ bond distance within the octahedra, Figure $8 \mathrm{~d}$. Simple bond valence sum calculations, ${ }^{19}$ based on oxidation of all the $\mathrm{Fe}^{2+}$ present to $\mathrm{Fe}^{3+}$, show that the changes observed are compatible with such a process. Since no low-temperature oxidation of $\mathrm{CoSb}_{2} \mathrm{O}_{4}$ occurs, Figure 2, we conclude that facile oxidation of $\mathrm{Co}^{2+}$ does not occur.

Figure 8e,f shows data with direct relevance to oxygen entering the channels. The change in distance between two $\mathrm{Sb} /$ $\mathrm{Pb}$ cations immediately across a given channel is seen in Figure $8 \mathrm{e}$ and shows a substantial decrease of $7 \%$ (from 4.00 to 3.73 $\AA$ ); this is largely responsible for the contraction in the unit cell a parameter (Figure $8 \mathrm{~b}$ ). The decrease in channel diameter is also consistent with the insertion of negative $\mathrm{O}^{2-}$ ions which can bond to the positive ions that form the channel walls, in this case $\mathrm{Sb}^{3+}$ and $\mathrm{Pb}^{2+}$. Since oxidation of $\mathrm{Pb}$-free schafarzikites display the same oxidation characteristics, lead cannot be actively involved in the oxidation mechanism, and the formation of $\mathrm{Sb}-\mathrm{O}$ bonds must occur. This bond formation is consistent with the change in the average bond length for the three $\mathrm{Sb} / \mathrm{Pb}-\mathrm{O} 1 / \mathrm{O} 2$ bonds, Figure $8 \mathrm{f}$. In marked contrast to the $\mathrm{Fe} / \mathrm{Co}-\mathrm{O}$ distances (Figure $8 \mathrm{~d}$ ), these bonds increase with the level of oxidation and cannot simply relate to oxidation of $\mathrm{Sb}^{3+}$ to $\mathrm{Sb}^{5+}$. Although BVS estimates are not straightforward because of the partial substitution of $\mathrm{Pb}$ on the $\mathrm{Sb}$ sites, Figure 8 f shows the predicted average bond distances derived from BVS calculations for this site when coordinated to both three and four oxygens. The calculations are weighted to include the contribution from $\mathrm{Pb}^{2+}$ ions. The figure supports the hypothesis that oxygen enters the channels and bonds to $\mathrm{Sb}$ to form 4coordinate $\mathrm{Sb}^{3+}$. However, it must be remembered that not all $\mathrm{Sb}^{3+}$ ions will be bonded to an extra $\mathrm{O}^{2-}$ ion, so the apparent quantitative agreement of the data in Figure $8 \mathrm{f}$ is partly coincidental.

The in situ structural examination gives significant information concerning the nature of the oxidation of $\mathrm{Co}_{0.25} \mathrm{Fe}_{0.75} \mathrm{Sb}_{1.75} \mathrm{~Pb}_{0.25} \mathrm{O}_{4}$ and hence other related phases. It is clear that oxidation of cations within the chains of octahedra occurs, but the level of interstitial oxygen is higher than this mechanism can support; in this respect, the data endorse the results from TGA analysis. At this stage, two mechanisms 


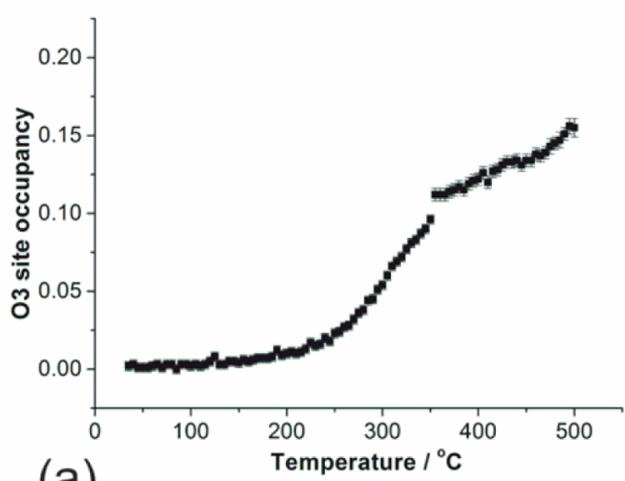

(a)

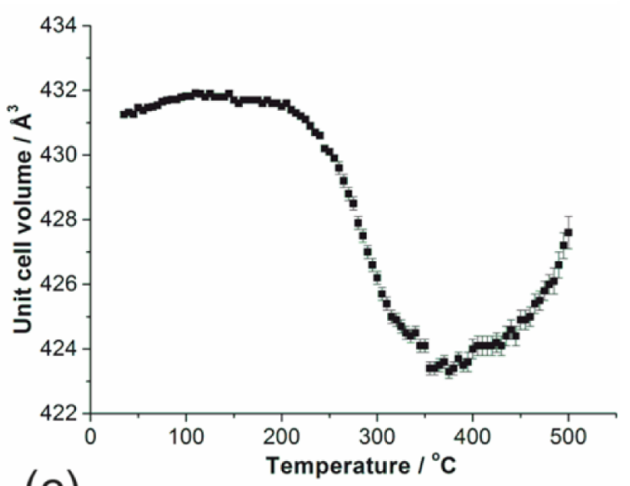

(c)

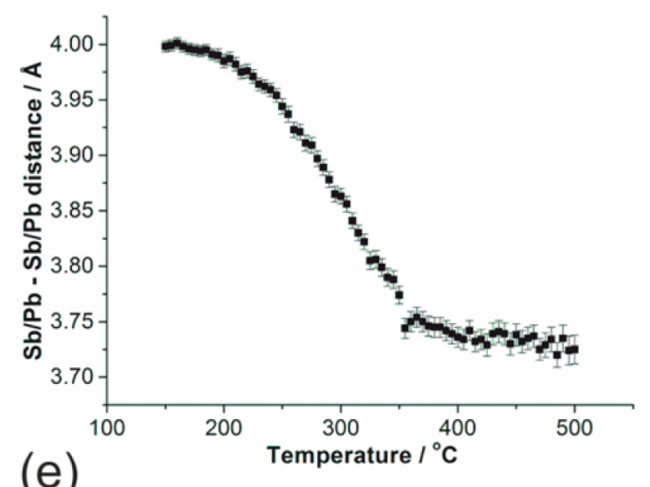

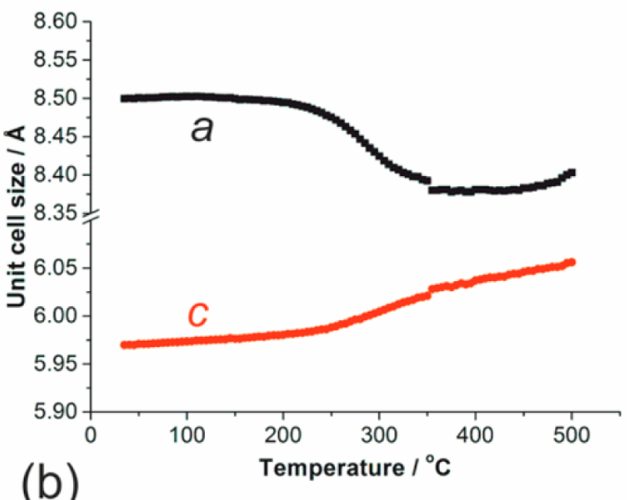

(b)

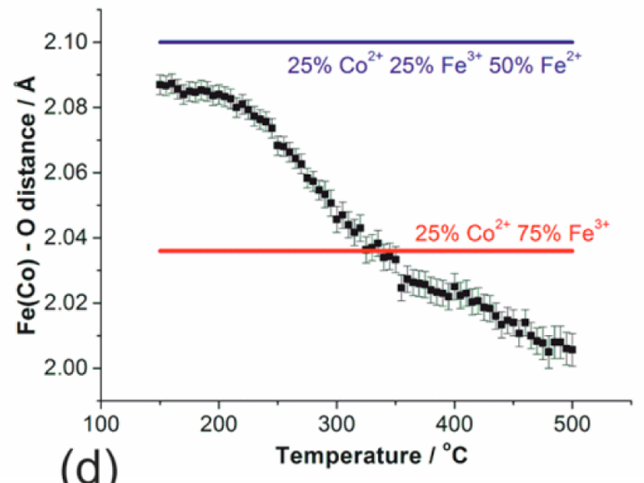

(d)

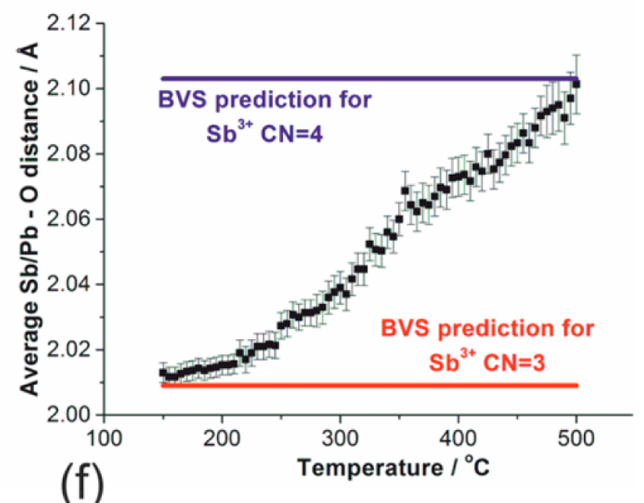

Figure 8. Variation with temperature of various structural parameters for $\mathrm{Co}_{0.25} \mathrm{Fe}_{0.75} \mathrm{Sb}_{1.75} \mathrm{~Pb}_{0.25} \mathrm{O}_{4}$ on heating in oxygen: (a) O3 site occupancy; (b) unit cell parameters; (c) unit cell volume; (d) average bond distance within the $\mathrm{MO}_{6}$ octahedra showing values predicted for oxidation of $\mathrm{Fe}^{2+}$ to $\mathrm{Fe}^{3+}$; (e) cation separation across the channel $(\mathrm{Sb} / \mathrm{Pb}-\mathrm{Sb} / \mathrm{Pb}) ;(\mathrm{f})$ average $\mathrm{Sb} / \mathrm{Pb}-\mathrm{O}$ (excluding interstitial O3). Error bars are included $( \pm 1$ esd) for all plots.

remained plausible to explain the enhanced oxygen content for the materials oxidized without phase decomposition:

(i) Peroxide links occur across the channels, e.g., $\mathrm{Sb}-\mathrm{O}-$ $\mathrm{O}-\mathrm{Sb}$ as shown in Figure 6;

(ii) Another oxidation process accompanies the oxidation of $\mathrm{Fe}^{2+}$ to $\mathrm{Fe}^{3+}$.

In order to resolve this uncertainty, additional information was sought from Raman spectroscopy, neutron PDF analysis, Mössbauer spectroscopy, NMR spectroscopy, and X-ray photoelectron spectroscopy (XPS); the results are discussed below and in Supporting Information.

3.4. Raman Spectroscopy. The best method to probe the existence of $-\mathrm{O}-\mathrm{O}-$ bonds is Raman spectroscopy for which the $\mathrm{O}-\mathrm{O}$ vibration is characterized by a band in the Raman shift range $750-850 \mathrm{~cm}^{-1} .^{21}$ The parent material, $\mathrm{FeSb}_{2} \mathrm{O}_{4}$, has previously been studied, and the strongest band at $668 \mathrm{~cm}^{-1}$ was assigned to a $\mathrm{Sb}-\mathrm{O}$ vibration with symmetry $A_{2 g}{ }^{22}$ We have examined a range of materials oxidized by heating in oxygen as previously described (vide supra) but have not found any evidence for a vibrational band to support the presence of peroxide (or superoxide). Figure 9, for example, shows spectra for $\mathrm{Co}_{0.75} \mathrm{Fe}_{0.25} \mathrm{Sb}_{2} \mathrm{O}_{4}$ before and after oxidation. The spectrum of the initial material agrees well with that previously described for $\mathrm{FeSb}_{2} \mathrm{O}_{4}{ }^{22}$ whereas the oxidized material has broadened bands which often show shoulders. The principal $\mathrm{Sb}-\mathrm{O}$ vibration shows such features which are to be expected because of the change in coordination of some of the $\mathrm{Sb}^{3+}$ ions following oxidation. However, no band in the $\mathrm{O}_{2}^{2-}$ region (or at 


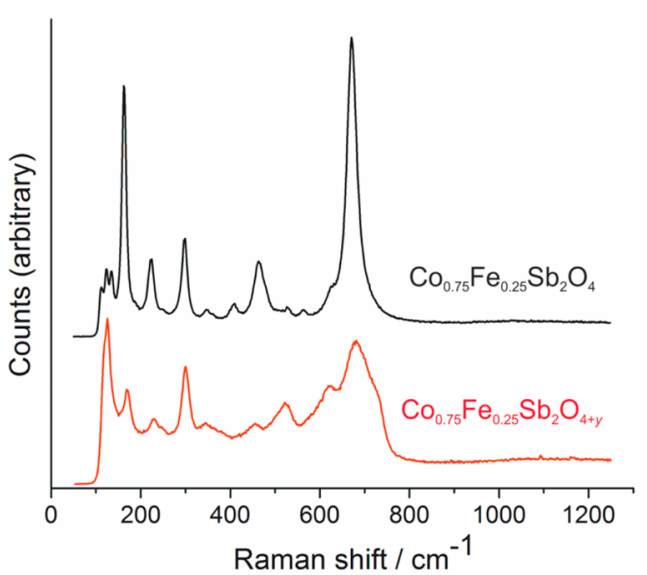

Figure 9. Raman spectra of $\mathrm{Co}_{0.75} \mathrm{Fe}_{0.25} \mathrm{Sb}_{2} \mathrm{O}_{4}$ and the oxidized product, $\mathrm{Co}_{0.75} \mathrm{Fe}_{0.25} \mathrm{Sb}_{2} \mathrm{O}_{4+y}$.

higher shifts compatible with $\mathrm{O}_{2}^{-}$) is seen which precludes the existence of such species in the oxidized compounds.

3.5. Mössbauer Spectroscopy. Since no low-temperature oxidation of $\mathrm{CoSb}_{2} \mathrm{O}_{4}$ occurs, Figure 2, $\mathrm{Co}^{2+}$ oxidation cannot occur under the low temperature oxidation conditions employed. The preferential oxidation of $\mathrm{Sb}^{3+}$ rather than $\mathrm{Co}^{2+}$ is supported by the formation of the trirutile $\mathrm{CoSb}_{2} \mathrm{O}_{6}$ (containing $\mathrm{Co}^{2+}$ and $\mathrm{Sb}^{5+}$ ). ${ }^{23}$ Similarly, the synthesis of $\mathrm{FePbBiO}_{4}$ (containing $\mathrm{Fe}^{3+}$ and $\mathrm{Pb}^{2+}$ ions) ${ }^{24}$ and $\mathrm{Pb}_{2} \mathrm{Sb}_{2} \mathrm{O}_{7}$ (containing $\mathrm{Sb}^{5+}$ and $\mathrm{Pb}^{2+}$ ions) ${ }^{25}$ under oxidizing conditions illustrates that $\mathrm{Pb}^{2+}$ ions are thermodynamically stable in the presence of $\mathrm{Fe}^{3+}$ and $\mathrm{Sb}^{5+}$ ions and will also remain unoxidized in the reactions under current discussion. The formation of $\mathrm{Fe}^{4+}$ ions in the presence of $\mathrm{Sb}^{3+}$ was considered highly unlikely, and the most plausible mechanism to explain the experimental obervations was one involving the simultaneous oxidation of $\mathrm{Fe}^{2+}$ (to $\mathrm{Fe}^{3+}$ ) and $\mathrm{Sb}^{3+}$ (to $\mathrm{Sb}^{5+}$ ) during the low temperature oxidation reaction. Since Mössbauer spectroscopy is the most powerful probe to determine $\mathrm{Fe}$ and $\mathrm{Sb}$ oxidation states, ${ }^{57} \mathrm{Fe}$ and ${ }^{121} \mathrm{Sb}$ Mössbauer spectra were collected to test this hypothesis. Although data were collected on a variety of materials, here we focus only on $\mathrm{Co}_{0.25} \mathrm{Fe}_{0.75} \mathrm{Sb}_{1.75} \mathrm{~Pb}_{0.25} \mathrm{O}_{4}$ and its oxidized product for which we are able to compare results with those from the detailed in situ NPD data.

Figures 10 and 11 show ${ }^{57} \mathrm{Fe}$ and ${ }^{121} \mathrm{Sb}$ Mössbauer spectra for the initial compound and the sample after oxidation in air at $350{ }^{\circ} \mathrm{C}$ for $3 \mathrm{~h}$, respectively. It can be seen that the absorption peaks from $\mathrm{Sb}^{3+}$ are suggestive of more than one component, which may relate to various factors including quadrupolar effects and the presence of more than one $\mathrm{Sb}^{3+}$ site postoxidation (vide infra). These are under investigation and will be reported later; for the present analysis, since the Fe and $\mathrm{Sb}$ oxidation states are of primary concern, the $\mathrm{Sb}^{3+}$ absorption peaks have been fitted to a single site, but quadrupole splitting effects have been included. Table 4 gives the detailed Mössbauer parameters. The ${ }^{57} \mathrm{Fe}$ spectrum for the initial material, Figure $10 \mathrm{a}$, suggests $58 \% \mathrm{Fe}^{2+}$ and $42 \% \mathrm{Fe}^{3+}$ based on the respective peak areas (Table 4). Correction of these ambient temperature data for $\mathrm{Fe}^{2+}$ and $\mathrm{Fe}^{3+}$ Debye-Waller factor effects (using thermal factors for $\mathrm{FeSb}_{2} \mathrm{O}_{4}{ }^{13}$ and $\mathrm{FePbBiO}_{4}{ }^{24}$ ) results in the composition $62 \% \mathrm{Fe}^{2+}$ and $38 \%$ $\mathrm{Fe}^{3+}$, in reasonable agreement with the values expected for an initial composition of $0.50 \mathrm{Fe}^{2+}$ and $0.25 \mathrm{Fe}^{3+}$ pfu $\left(67 \% \mathrm{Fe}^{2+}\right.$ and $\left.33 \% \mathrm{Fe}^{3+}\right)$.
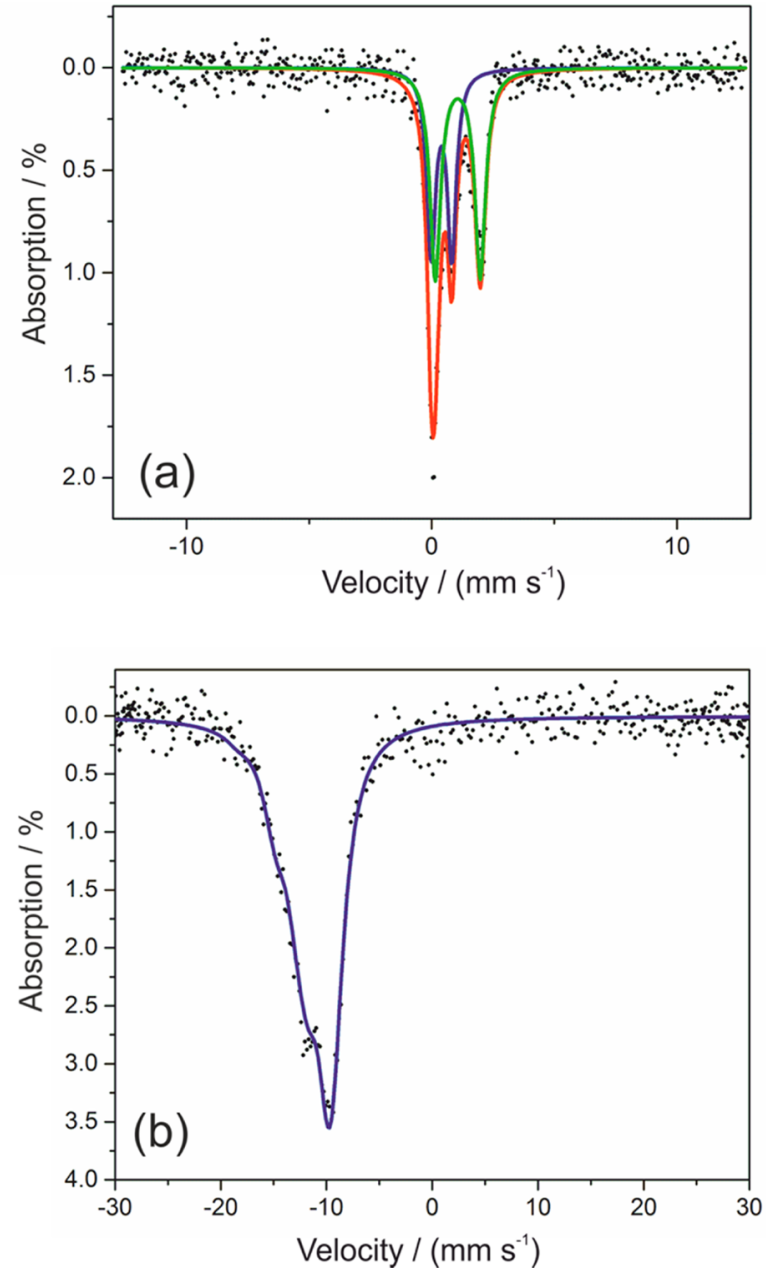

Figure 10. Mössbauer spectra for $\mathrm{Co}_{0.25} \mathrm{Fe}_{0.75} \mathrm{Sb}_{1.75} \mathrm{~Pb}_{0.25} \mathrm{O}_{4}$ : (a) ${ }^{57} \mathrm{Fe}$ spectrum showing the individual fitting of $\mathrm{Fe}^{2+}$ (green line) and $\mathrm{Fe}^{3+}$ (blue line), and the overall fit (red line); (b) ${ }^{121} \mathrm{Sb}$ spectrum showing the fit to $\mathrm{Sb}^{3+}$ alone (blue line).

Full oxidation of $\mathrm{Fe}^{2+}$ to $\mathrm{Fe}^{3+}$ is indicated in the product of oxidation at $350{ }^{\circ} \mathrm{C}$, Figure 11a, but no evidence for higher oxidation states of $\mathrm{Fe}$ has been observed; the formation of $\mathrm{Fe}^{4+}$ was therefore eliminated from the oxidation mechanism. The partial oxidation of $\mathrm{Sb}^{3+}$ to $\mathrm{Sb}^{5+}$ indicated in the ${ }^{121} \mathrm{Sb}$ spectrum in Figure $11 \mathrm{~b}$ is therefore of major significance. The peak areas in the ${ }^{121} \mathrm{Sb}$ Mössbauer data recorded at $90 \mathrm{~K}$, Table 4, are necessary to provide a reliable estimate for the $\mathrm{Sb}^{5+}$ concentration $(18(5) \%)$. The difference between this value and that deduced from the peak areas in the ambient temperature data $(22(5) \%)$ is expected because of the significantly higher Debye-Waller factor for the lower valent $\mathrm{Sb}^{3+}$ ion (compared with $\mathrm{Sb}^{5+}$ ) and the resulting lower recoilfree fraction at $300 \mathrm{~K}$ for $\mathrm{Sb}^{3+}$ compared with $\mathrm{Sb}^{5+}$. At $90 \mathrm{~K}$, the recoil-free fractions for both oxidation states are similar. For $18(5) \%$ conversion of $\mathrm{Sb}^{3+}$ to $\mathrm{Sb}^{5+}$ (Table 4) and all Fe being present as $\mathrm{Fe}^{3+}$, the final composition would be $\mathrm{Co}_{0.25} \mathrm{Fe}_{0.75} \mathrm{Sb}_{1.75} \mathrm{~Pb}_{0.25} \mathrm{O}_{4.57(9)}$, which is in excellent agreement with the NPD data in Figure 8a which suggests an oxygen content of $4.50 \mathrm{pfu}$. The critical conclusion is that the oxidation process at $350{ }^{\circ} \mathrm{C}$ does indeed relate to the oxidation of both $\mathrm{Fe}^{2+}$ to $\mathrm{Fe}^{3+}$ and $\mathrm{Sb}^{3+}$ to $\mathrm{Sb}^{5+}$. We note that two $\mathrm{Fe}^{2+}$ ions $(0.50$ $\mathrm{pfu})$ are oxidized for one $\mathrm{Sb}^{3+}(14.3 \% \mathrm{Sb}$ corresponds to 0.25 $\mathrm{Sb} \mathrm{pfu})$, and this is discussed in detail later. 

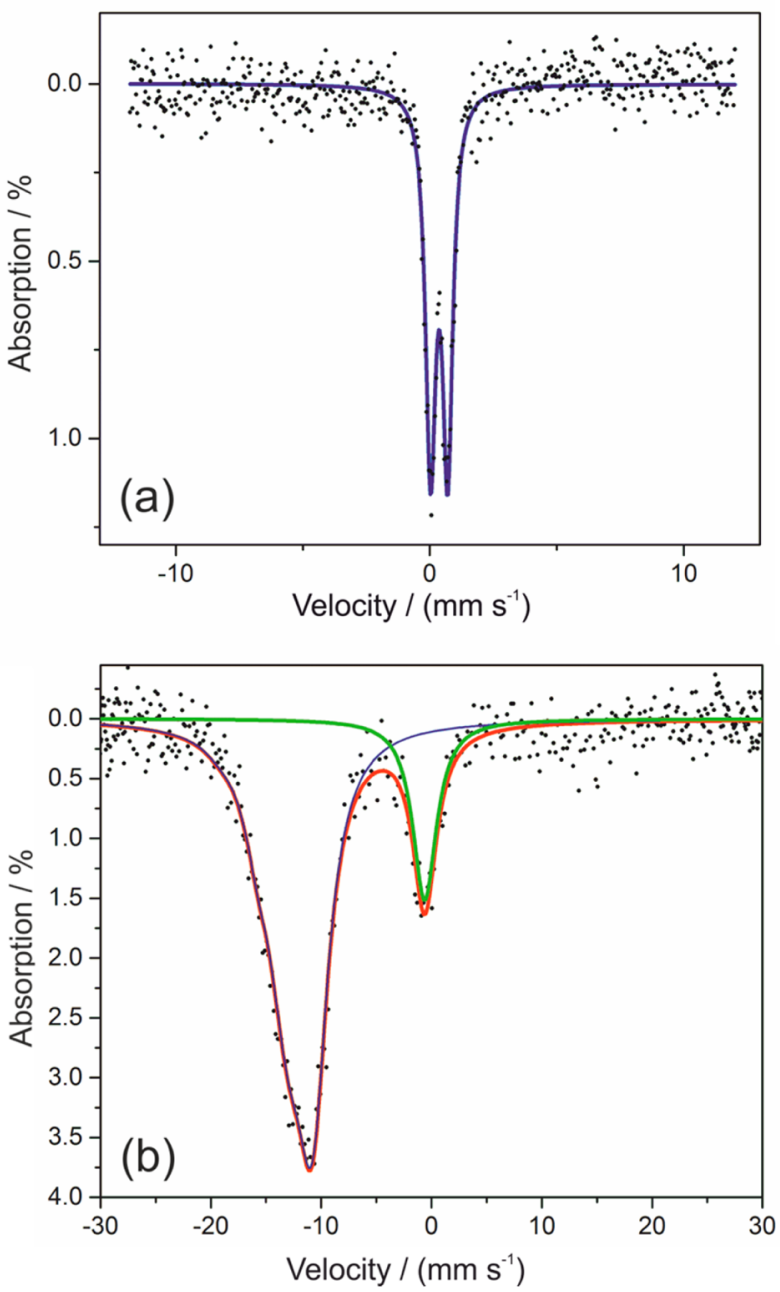

Figure 11. Mössbauer spectra for $\mathrm{Co}_{0.25} \mathrm{Fe}_{0.75} \mathrm{Sb}_{1.75} \mathrm{~Pb}_{0.25} \mathrm{O}_{4}$ after heating at $350{ }^{\circ} \mathrm{C}$ : (a) ${ }^{57} \mathrm{Fe}$ spectrum showing the fitting to $\mathrm{Fe}^{3+}$ (blue line); (b) ${ }^{121} \mathrm{Sb}$ spectrum showing the individual fits for $\mathrm{Sb}^{3+}$ (blue line) and $\mathrm{Sb}^{5+}$ (green line), and the overall fit (red line).

Mössbauer data were also collected for a sample heated slowly to $500{ }^{\circ} \mathrm{C}$ in oxygen, held for $1 \mathrm{~h}$, and then slowly cooled; the results are given in Figure 12 and Table 4. As expected, the $\mathrm{Fe}^{2+}$ was fully oxidized to $\mathrm{Fe}^{3+}$ and more $\mathrm{Sb}^{3+}$ was oxidized to $\mathrm{Sb}^{5+}$ to yield a composition of $\mathrm{Co}_{0.25} \mathrm{Fe}_{0.75} \mathrm{Sb}_{1.75} \mathrm{~Pb}_{0.25} \mathrm{O}_{4.93}$. This compares with the compositions revealed by NPD for a sample heated at $500{ }^{\circ} \mathrm{C}$ but under two different overall synthetic conditions: at the end of the ramping to $500{ }^{\circ} \mathrm{C}$, the oxygen content is $\mathrm{O}_{4.64(2)}$ (Figure 8a); after holding at $500{ }^{\circ} \mathrm{C}$ for an hour it has risen to $\mathrm{O}_{4.74(2)}$. These three compositions $-\mathrm{O}_{4.64}, \mathrm{O}_{4.74}$ and $\mathrm{O}_{4.93}$-correspond to samples approximately at the beginning, middle, and end of the higher temperature plateau shown in Figure 2, and the differences in composition can be attributed to kinetic factors. The Mössbauer data are therefore strongly supportive of a twostep low-temperature oxidation process (i.e., prior to full oxidation at temperatures $>\sim 600{ }^{\circ} \mathrm{C}$ ). These steps are reflected in the two low-temperature plateau regions that occur in the TGA plots (Figure 2) and the difference in structural trends that are observed in the in situ NPD data below and above $350{ }^{\circ} \mathrm{C}$ (Figure 8) and discussed in section 3.3. The oxidation processes relate to synchronous oxidation of $\mathrm{Fe}^{2+}$ to $\mathrm{Fe}^{3+}$ and $\mathrm{Sb}^{3+}$ to $\mathrm{Sb}^{5+}$ below $\sim 350{ }^{\circ} \mathrm{C}$ (until all $\mathrm{Fe}^{2+}$ is
Table 4. ${ }^{57} \mathrm{Fe}$ and ${ }^{121} \mathrm{Sb}$ Mössbauer Parameters for $\mathrm{Co}_{0.25} \mathrm{Fe}_{0.75} \mathrm{Sb}_{1.75} \mathrm{~Pb}_{0.25} \mathrm{O}_{4}$ and $\mathrm{Co}_{0.25} \mathrm{Fe}_{0.75} \mathrm{Sb}_{1.75} \mathrm{~Pb}_{0.25} \mathrm{O}_{4+\mathrm{y}}$ after heating at $350{ }^{\circ} \mathrm{C}$ and $500{ }^{\circ} \mathrm{C}$

\begin{tabular}{lccrr} 
sample & $\begin{array}{c}\text { temperature of } \\
\text { measurement/K }\end{array}$ & $\begin{array}{c}\Delta \text { or } \mathrm{e}^{2} \mathrm{qQ}_{\mathrm{g}} \\
( \pm 0.06) / \mathrm{mm} \mathrm{s}^{-1}\end{array}$ & $\begin{array}{c}\delta( \pm 0.03) \\
/ \mathrm{mm} \mathrm{s}^{-1}\end{array}$ & $\begin{array}{r}\text { area } \\
( \pm 5) / \%\end{array}$ \\
$\mathrm{Fe}^{2+}$ & 298 & $\mathrm{Co}_{0.25} \mathrm{Fe}_{0.75} \mathrm{Sb}_{1.75} \mathrm{~Pb}_{0.25} \mathrm{O}_{4}$ \\
$\mathrm{Fe}^{3+}$ & 298 & 1.84 & 1.06 & 58 \\
$\mathrm{Sb}^{3+}$ & 298 & 0.84 & 0.41 & 42 \\
$\mathrm{Sb}^{5+}$ & 298 & +8.35 & -11.02 & 100 \\
$\mathrm{Sb}^{3+}$ & 90 & & & 0 \\
$\mathrm{Sb}^{5+}$ & 90 & +18.63 & -11.08 & 100 \\
& $\mathrm{Co}_{0.25} \mathrm{Fe}_{0.75} \mathrm{Sb}_{1.75} \mathrm{~Pb}_{0.25} \mathrm{O}_{4+y}$ heated at $350{ }^{\circ} \mathrm{C}$ & 0 \\
$\mathrm{Fe}^{2+}$ & 298 & & & 0 \\
$\mathrm{Fe}^{3+}$ & 298 & 0.67 & 0.39 & 100 \\
$\mathrm{Sb}^{3+}$ & 298 & +8.44 & -11.80 & 78 \\
$\mathrm{Sb}^{5+}$ & 298 & & -0.50 & 22 \\
$\mathrm{Sb}^{3+}$ & 90 & +17.57 & -12.14 & 82 \\
$\mathrm{Sb}^{5+}$ & 90 & & -0.55 & 18 \\
& $\mathrm{Co}_{0.25} \mathrm{Fe}_{0.75} \mathrm{Sb}_{1.75} \mathrm{~Pb}_{0.25} \mathrm{O}_{4+y}$ heated at & & \\
$\mathrm{F}^{2+} \mathrm{C}$ & \\
$\mathrm{Fe}^{2+}$ & 298 & & & 0 \\
$\mathrm{Fe}^{3+}$ & 298 & 0.84 & 0.37 & 100 \\
$\mathrm{Sb}^{3+}$ & 298 & +8.16 & -12.50 & 53 \\
$\mathrm{Sb}^{5+}$ & 298 & & -0.57 & 47 \\
$\mathrm{Sb}^{3+}$ & 90 & & -12.59 & 58 \\
$\mathrm{Sb}^{5+}$ & 90 & & -0.46 & 42 \\
\hline
\end{tabular}

oxidized), and subsequent further oxidation of $\mathrm{Sb}^{3+}$ to $\mathrm{Sb}^{5+}$ at higher temperatures.

3.6. ${ }^{17} \mathrm{O}$ NMR Spectroscopy. In order to obtain additional information concerning the nature of oxygen absorption, especially with respect to possible peroxide formation, ${ }^{17} \mathrm{O}$ NMR spectra were recorded for $\mathrm{Fe}^{2+}$-containing samples after oxidation in ${ }^{17} \mathrm{O}$-enriched oxygen gas. To assist the interpretation of the spectra, the ${ }^{17} \mathrm{O}$ and ${ }^{25} \mathrm{Mg}$ MAS NMR data of the diamagnetic $\mathrm{MgSb}_{2} \mathrm{O}_{4}$ and $\mathrm{Sb}_{2} \mathrm{O}_{3}$ systems were also obtained and are shown in Figure 13; the measured NMR parameters and the associated GIPAW DFT calculated parameters are summarized in Table 5 . The variable $B_{0}$ field ${ }^{17} \mathrm{O}$ MAS NMR data of Figure 13a shows the presence of two resonances associated with the apical and equatorial positions in the $\mathrm{MgSb}_{2} \mathrm{O}_{4}$ lattice; these are denoted as sites 1 and 2, respectively, and correspond to $\mathrm{O} 1$ and $\mathrm{O} 2$ in Figure 1 and Tables 2 and 3. In addition, channel $\mathrm{H}_{2} \mathrm{O}$ and surface $\mathrm{OH}^{-}$ species are observed. The presence of all four $\mathrm{O}$ species is corroborated by the ${ }^{17} \mathrm{O} 2 \mathrm{D} 3 \mathrm{QMAS}$ data of Figure $1 \mathrm{~b}$. A comparison of the $\delta_{\text {iso }}$ and $P_{\mathrm{Q}}$ values elucidated from the variable $B_{0}$ field analysis of the data characterizing sites 1 and 2 (see Figure 13c) with the corresponding calculated GIPAW DFT values demonstrates that only one of the $O$ positions exhibits a good agreement between measurement and calculation. Furthermore, the ${ }^{25} \mathrm{Mg} \delta_{\text {iso }}, P_{\mathrm{Q}}, C_{\mathrm{Q}}$, and $\eta$ parameters measured from the data of Figure $13 \mathrm{~d}$ are in excellent agreement with the GIPAW DFT calculated values, especially after geometry optimization. Hence, it can be inferred that the residual $\mathrm{H}_{2} \mathrm{O}$ and $\mathrm{OH}^{-}$speciation in the channels selectively influence only one of the framework $\mathrm{O}$ positions. Similar evidence of this selective influence emanates from the ${ }^{17} \mathrm{O}$ MAS NMR data from $\mathrm{Sb}_{2} \mathrm{O}_{3}$ shown in Figure 13e; although the apical and equatorial $\mathrm{O}$ positions of $\mathrm{MgSb}_{2} \mathrm{O}_{4}$ are comparable, possessing similar arrangements with the $\mathrm{Sb}$ positions, only the apical site 1 exhibits $\delta_{\text {iso }}, C_{\mathrm{Q}}$, and $\eta$ values 

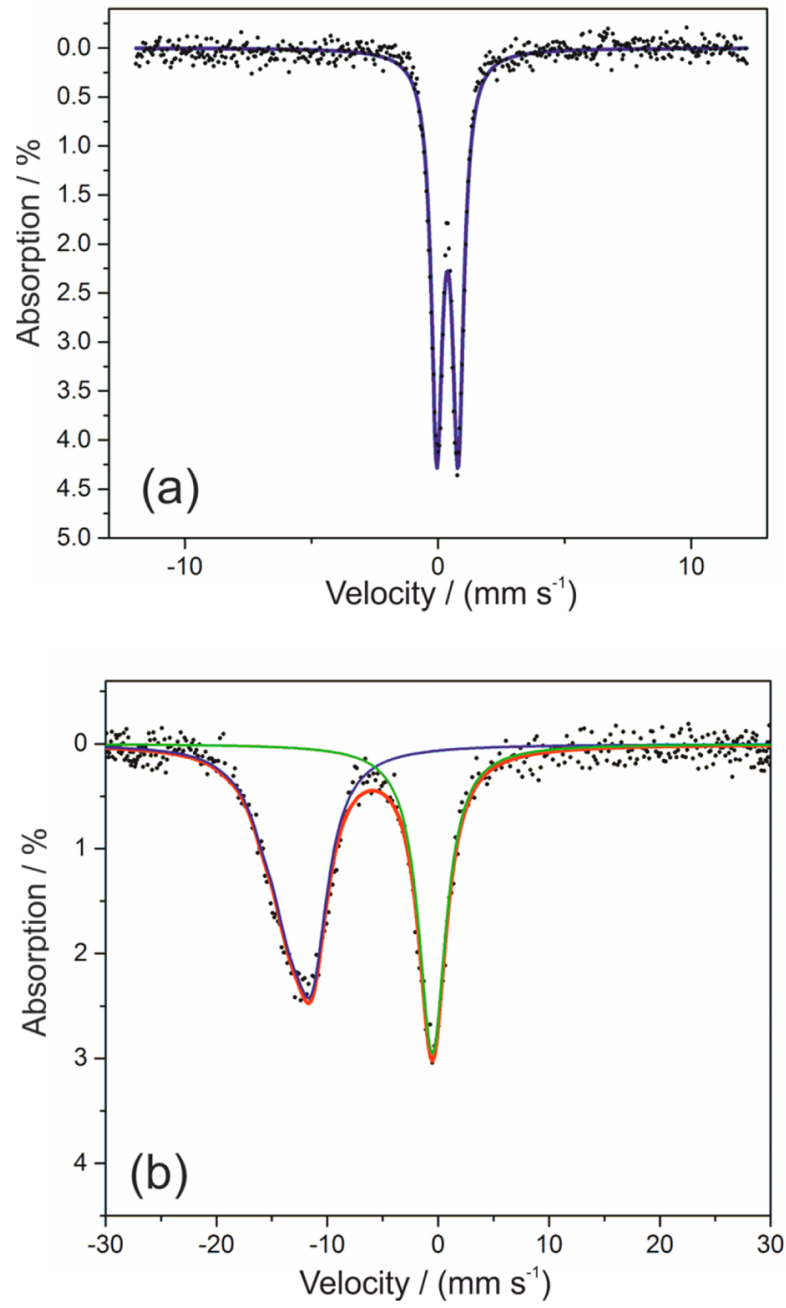

Figure 12. Mössbauer spectra for $\mathrm{Co}_{0.25} \mathrm{Fe}_{0.75} \mathrm{Sb}_{1.75} \mathrm{~Pb}_{0.25} \mathrm{O}_{4}$ after heating at $500{ }^{\circ} \mathrm{C}$ : (a) ${ }^{57} \mathrm{Fe}$ spectrum showing the fitting to $\mathrm{Fe}^{3+}$ (blue line); (b) ${ }^{121} \mathrm{Sb}$ spectrum showing the individual fits for $\mathrm{Sb}^{3+}$ (blue line) and $\mathrm{Sb}^{5+}$ (green line), and the overall fit (red line).

that are in agreement with the $\mathrm{Sb}_{2} \mathrm{O}_{3}$ unit, thus suggesting that the interaction with channel $\mathrm{H}_{2} \mathrm{O}$ and surface $\mathrm{OH}^{-}$species influences the equatorial site 2 represented by the upfield resonance.

Solid state ${ }^{17} \mathrm{O}$ NMR studies on paramagnetic materials are uncommon due to $\mathrm{O}$ typically being directly bonded (or in close spatial proximity) to paramagnetic species. ${ }^{30}$ The ${ }^{17} \mathrm{O}$ MAS NMR data of the paramagnetic schafarzikite-related systems shown in Figure 14 are hyperfine shifted, presumably by contributions from both the pseudocontact shift and the Fermi contact interactions. These spectra exhibit broad characteristic anisotropies which are represented as manifolds of spinning sidebands that are usually associated with the pseudocontact shift contribution. Through the implementation of variable MAS frequencies the isotropic position of each sideband manifold has been determined. It is proposed that the narrow ${ }^{17} \mathrm{O}$ resonances at $\delta_{\text {iso }} \sim 2150$ and $\sim 1850 \mathrm{ppm}$ represent the high symmetry axial and equatorial oxygen environments of the framework which corroborates the NPD results. A substantial amount of labeled $O$ is located in the channels and is responsible for the broad underlying component $(\operatorname{span} \Delta \delta \approx 0-4,000 \mathrm{ppm})$ that resides underneath the better defined spinning sideband manifolds (see Figure
$14 \mathrm{~b}-\mathrm{e})$. This observation is also supported by the NPD refinement, with the broad nature of this resonance indicating a clear lack of order in these channel $\mathrm{O}$ environments. A direct comparison of the ${ }^{17} \mathrm{O}$ MAS NMR data measured from diamagnetic $\mathrm{MgSb}_{2} \mathrm{O}_{4}$ (see Figure 14a) with the paramagnetic schafarzikite-related systems shown in Figure $14 \mathrm{~b}-\mathrm{e}$ indicates that the magnitude of the paramagnetic shifts and anisotropies are dependent on the nominal composition and the relative amounts of the paramagnetic $\mathrm{Co}^{2+}, \mathrm{Fe}^{2+}$, and $\mathrm{Fe}^{3+}$ defining each system.

The NMR data therefore show significant ${ }^{17} \mathrm{O}$ substitution at the lattice $\mathrm{O} 1$ (apical) and $\mathrm{O} 2$ (equatorial) sites following short oxygen incorporation reactions. This indicates that oxide ion diffusion is occurring within the structural framework in addition to that within the channels. The broad signals from the channel sites prevent definitive characterization of their environment, but do not support the presence of peroxide bond formation.

3.7. Electronic Conductivity. Conductivity data were collected on pellets of $\mathrm{Co}_{0.50} \mathrm{Fe}_{0.50} \mathrm{Sb}_{2} \mathrm{O}_{4}$ under three conditions: ramping up to $500{ }^{\circ} \mathrm{C}$ in dry nitrogen; ramping up to $500{ }^{\circ} \mathrm{C}$ in air and then cooling; ramping to $350{ }^{\circ} \mathrm{C}$ under dry nitrogen and then switching the atmosphere to dry oxygen under isothermal conditions. The results are shown in Figure 15. Figure 15a shows, in blue, the variation of the conductivity of the starting material with temperature (the heating is in nitrogen gas). The black lines/symbols show the major effects of heating in air: the oxidation begins at ca. $260{ }^{\circ} \mathrm{C}$ and results in an increase in conductivity; the conductivity peaks at $330^{\circ} \mathrm{C}$ and then falls to a value below that of the starting material heated in nitrogen. This behavior reflects the increased electronic conductivity caused by the presence of both $\mathrm{Fe}^{2+}$ and $\mathrm{Fe}^{3+}$ ions and was seen previously for the system $\mathrm{FeSb}_{2-x} \mathrm{~Pb}_{x} \mathrm{O}_{4}{ }^{13}$ where the conductivity was highest for equal $\mathrm{Fe}^{2+}$ and $\mathrm{Fe}^{3+}$ concentrations. The same data plotted as $\log$ (conductivity) against $1000 / \mathrm{T}$ are shown in Figure $15 \mathrm{~b}$ where the red lines are linear fits to the data prior to oxidation and on cooling of the oxidized product. The good fits indicate thermally promoted conduction with activation energies of $19.5(2) \mathrm{kJ} \mathrm{mol}^{-1}$ and 21.3(2) $\mathrm{kJ} \mathrm{mol}^{-1}$ for the unoxidized and oxidized materials, respectively. The conductivity for $\mathrm{Co}_{0.50} \mathrm{Fe}_{0.50} \mathrm{Sb}_{2} \mathrm{O}_{4}$ is approximately an order of magnitude lower than that reported for $\mathrm{FeSb}_{2} \mathrm{O}_{4},{ }^{13}$ which suggests that electron migration primarily involves $\mathrm{Fe}^{2+}$. Figure $15 \mathrm{~b}$ shows that the conductivity of the oxidized phase, $\mathrm{Co}_{0.50} \mathrm{Fe}_{0.50} \mathrm{Sb}_{2} \mathrm{O}_{4+y}$, is lower than that for $\mathrm{Co}_{0.50} \mathrm{Fe}_{0.50} \mathrm{Sb}_{2} \mathrm{O}_{4}$ by a factor of about 5 . Since the conduction will be dominated by the chains of octahedral transition metals, this is probably linked to the expansion along [001], the chain direction, during oxidation and the resulting effect on $\mathrm{Fe}-\mathrm{Fe}$ separation. It should be noted that the small discrepancy between the measurement in nitrogen and the low temperature measurement in air can be traced to a significant difference in pellet densities: $50 \%$ for the pellet in air cf. $77 \%$ for the pellet in nitrogen.

Figure $15 \mathrm{c}$ reports data for subsequent isothermal oxidation at $350{ }^{\circ} \mathrm{C}$ of the pellet that had previously been heated in nitrogen to provide the data (in blue) shown in Figure 15a,b. The data are recorded against time after the gas was switched from nitrogen to oxygen. After an initial delay corresponding to gas diffusion in the system, virtually complete pellet oxidation is achieved after approximately $7 \mathrm{~min}$. This rapid reaction suggests the likelihood of high oxide ion mobility for the interstitial ions within the channels of these materials. 

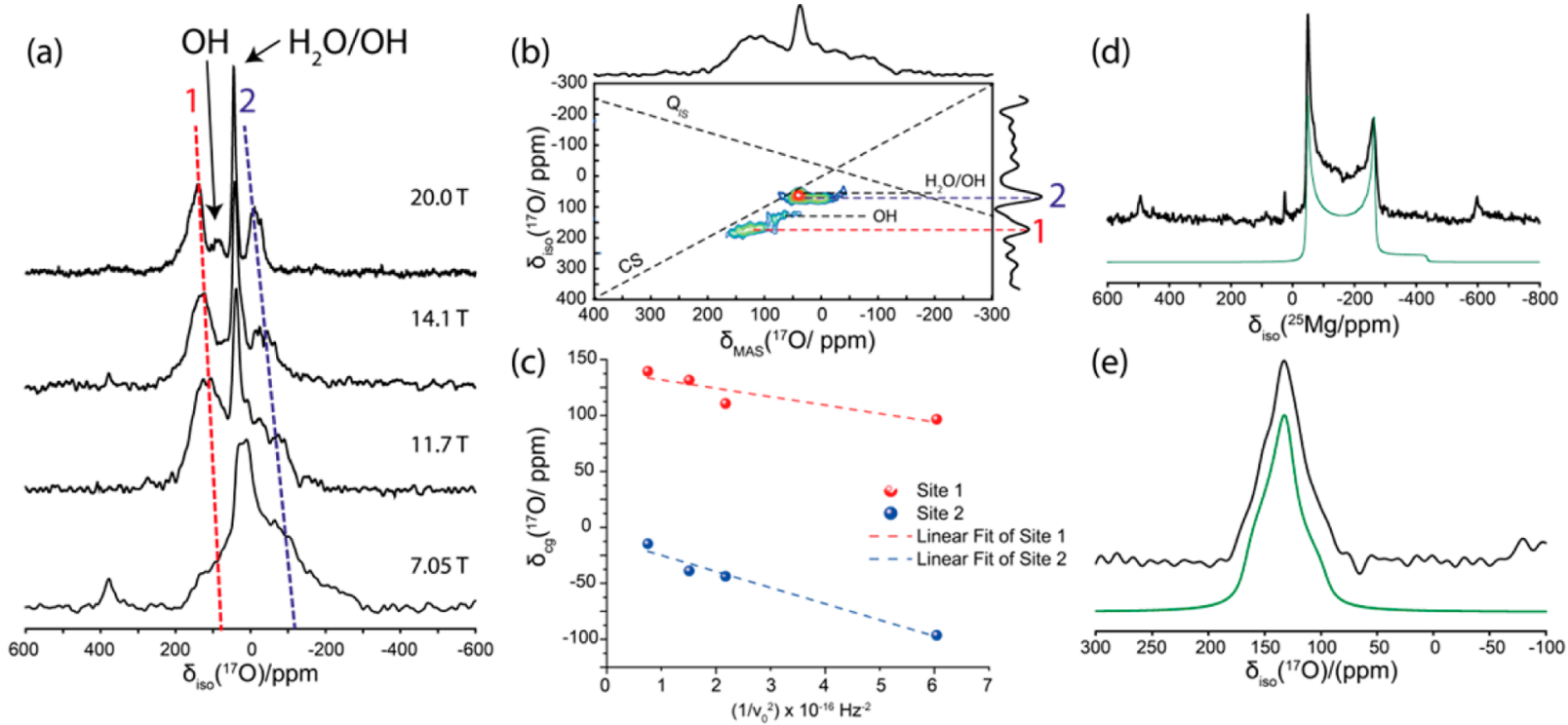

Figure 13. (a) Multi- $B_{0}$ field ${ }^{17} \mathrm{O}$ MAS NMR data $\left(\nu_{\mathrm{r}}=20 \mathrm{kHz}\right)$, (b) ${ }^{17} \mathrm{O} 3 \mathrm{QMAS}\left(\nu_{\mathrm{r}}=20 \mathrm{kHz}\right)$ and (c) graphical analysis of the multi- $B_{0}$ field yielding estimates of $\delta_{\text {iso }}$ and the quadrupole product $P_{\mathrm{Q}}$ from hydrothermally ${ }^{17} \mathrm{O}$ labeled $\mathrm{MgSb}_{2} \mathrm{O}_{4}$. The ${ }^{25} \mathrm{Mg} \mathrm{MAS} \mathrm{NMR}$ data from ${ }^{25} \mathrm{Mg}$ enriched high temperature calcined $\mathrm{MgSb}_{2} \mathrm{O}_{4}$ is shown in (d), while the ${ }^{17} \mathrm{O}$ MAS NMR data from hydrothermally ${ }^{17} \mathrm{O}$ labeled $\mathrm{Sb}_{2} \mathrm{O}_{3}$ is shown in (e).

Table 5. Experimentally Determined and GIPAW DFT Calculated NMR Parameters $\left(\delta_{\text {iso }}, C_{\mathrm{Q}}, \eta\right.$, and $\left.P_{\mathrm{Q}}\right)$ from the Diamagnetic $\mathrm{MgO}, \mathrm{Sb}_{2}{ }^{17} \mathrm{O}_{3}$, and $\mathrm{MgSb}_{2}{ }^{17} \mathrm{O}_{4}$ Systems

\begin{tabular}{|c|c|c|c|c|c|c|c|c|c|c|c|c|c|c|}
\hline \multirow[b]{2}{*}{ sample } & \multirow[b]{2}{*}{ site } & \multicolumn{3}{|c|}{ experimental } & \multirow[b]{2}{*}{$\begin{array}{c}\mathrm{C}_{\mathrm{Q}} \\
(\mathrm{MHz})\end{array}$} & \multirow[b]{2}{*}{$\eta$} & \multirow[b]{2}{*}{$\underset{(\mathrm{MHz})}{P_{\mathrm{Q}}}$} & \multirow[b]{2}{*}{$\begin{array}{c}P_{\mathrm{Q}} \text { error } \\
(\mathrm{MHz})\end{array}$} & \multirow{2}{*}{$\frac{\text { CASTEP }}{\begin{array}{c}\text { geom. } \\
\text { opt. }\end{array}}$} & \multirow[b]{2}{*}{$\begin{array}{c}\sigma \\
(\mathrm{ppm})\end{array}$} & \multirow[b]{2}{*}{$\begin{array}{c}\delta_{\text {iso }} \\
(\mathrm{ppm})\end{array}$} & \multirow[b]{2}{*}{$\begin{array}{c}\mathrm{C}_{\mathrm{Q}} \\
(\mathrm{MHz})\end{array}$} & \multirow[b]{2}{*}{$\eta$} & \multirow[b]{2}{*}{$\begin{array}{c}P_{\mathrm{Q}} \\
(\mathrm{MHz})\end{array}$} \\
\hline & & isotope & $\begin{array}{c}\delta_{\text {iso }} \\
(\mathrm{ppm})\end{array}$ & $\begin{array}{c}\delta_{\text {iso }} \text { error } \\
(\mathrm{ppm})\end{array}$ & & & & & & & & & & \\
\hline $\mathrm{MgO}^{26}$ & 1 & ${ }^{25} \mathrm{Mg}$ & 26 & & & & & & no & 535.2 & $26^{a}$ & 0 & 0 & 0 \\
\hline $\mathrm{Sb}_{2} \mathrm{O}_{3}{ }^{27}$ & 1 & ${ }^{17} \mathrm{O}$ & 167 & & 5.2 & 0.99 & & & no & 70.8 & $167^{b}$ & 5.93 & 0.93 & 6.73 \\
\hline \multirow[t]{3}{*}{$\mathrm{MgSb}_{2} \mathrm{O}_{4}{ }^{28}$} & 1 & ${ }^{17} \mathrm{O}$ & -11 & \pm 3 & & & 4.9 & \pm 0.3 & no & 50.2 & 146.1 & 4.47 & 0.00 & 4.47 \\
\hline & 2 & ${ }^{17} \mathrm{O}$ & 139 & \pm 4 & & & 3.5 & \pm 0.6 & & 67.1 & 163.0 & 5.49 & 0.56 & 5.77 \\
\hline & 1 & ${ }^{25} \mathrm{Mg}$ & 19 & & 6.4 & 0.00 & & & & 528.9 & 19.8 & 5.89 & 0.14 & 5.90 \\
\hline \multirow[t]{3}{*}{$\mathrm{MgSb}_{2} \mathrm{O}_{4}{ }^{28}$} & 1 & ${ }^{17} \mathrm{O}$ & -11 & \pm 3 & & & 4.9 & \pm 0.3 & yes & 33.3 & 104.1 & 4.64 & 0.00 & 4.64 \\
\hline & 2 & ${ }^{17} \mathrm{O}$ & 139 & \pm 4 & & & 3.5 & \pm 0.6 & & 55.7 & 151.6 & 5.62 & 0.54 & 5.89 \\
\hline & 1 & ${ }^{25} \mathrm{Mg}$ & 19 & & 6.4 & 0.00 & & & & 531.5 & 22.3 & 5.56 & 0.04 & 5.56 \\
\hline
\end{tabular}

${ }^{a} \sigma_{\text {ref }}$ from Dupree and Smith. ${ }^{29}{ }^{b}$ Measured $\sigma_{\text {ref }}$ given in Figure 13e.

\section{DISCUSSION}

The NPD and TGA data clearly indicate that low-temperature oxidation of schafarzikite materials that contain both $\mathrm{Fe}^{2+}$ and $\mathrm{Sb}^{3+}$ is associated with oxygen entering the channels and bonding to $\mathrm{Sb}^{3+}$ ions. However, the level of oxygen incorporation is greater than that corresponding to oxidation of $\mathrm{Fe}^{2+}$ to $\mathrm{Fe}^{3+}$ within the octahedral chains. Moreover, the data consistently suggest that for $\mathrm{Fe}^{2+}$ concentrations of $<0.5 \mathrm{pfu}$ in the unoxidised samples, the oxygen uptake is ca. twice that expected. Mössbauer spectra reveal that charge balance associated with the extra oxygen content is provided by oxidation of $\mathrm{Sb}^{3+}$ to $\mathrm{Sb}^{5+}$. To examine the change in oxidation states of all four cations in $\mathrm{Co}_{0.25} \mathrm{Fe}_{0.75} \mathrm{Sb}_{1.75} \mathrm{~Pb}_{0.25} \mathrm{O}_{4}$, XPS data were collected but the changes observed were insufficient to resolve the details of the redox reactions. However, oxidation of neither $\mathrm{Co}^{2+}$ nor $\mathrm{Pb}^{2+}$ is plausible as discussed in Section 3.6. With respect to the formation of $\mathrm{Sb}^{5+}$ ions, it is relevant to note that an attempt to partially substitute $\mathrm{Sb}^{3+}$ by $\mathrm{Pb}^{2+}$ in $\mathrm{MnSb}_{2} \mathrm{O}_{4}{ }^{11}$ resulted in oxidation of $\mathrm{Sb}^{3+}$ rather than the desired $\mathrm{Mn}^{2+}$, and the resulting $\mathrm{Sb}^{5+}$ ions entered the octahedral sites by replacing some of the $\mathrm{Mn}^{2+}$ ions. This possibility was rejected for the oxidations studied here for two reasons: (1) substitution of $\mathrm{Sb}^{5+}$ ions in the chains of octahedra would result in significant impurity phases; (2) PXRD and NPD are both sensitive to such mixing and both confirm that no detectable substitution of $\mathrm{Sb}$ within the chains occurs. The $\mathrm{Sb}^{5+}$ ions therefore remain on the channel walls, and it is therefore important to consider how the insertion of oxygen ions into the $\mathrm{O} 3$ sites can satisfy the very different stereochemical preferences of $\mathrm{Sb}^{3+}$ and $\mathrm{Sb}^{5+}$ ions.

For the oxidation of $\mathrm{Co}_{0.25} \mathrm{Fe}_{0.75} \mathrm{Sb}_{1.75} \mathrm{~Pb}_{0.25} \mathrm{O}_{4}$, the first low temperature plateau corresponds closely to oxidation of all $\mathrm{Fe}^{2+}$ to $\mathrm{Fe}^{3+}\left(0.50 \mathrm{Fe}^{2+}\right.$ forming $\left.0.50 \mathrm{Fe}^{3+}\right)$ and the simultaneous oxidation of $0.25 \mathrm{Sb}^{3+}$ to $0.25 \mathrm{Sb}^{5+}$; this would correspond to an oxygen content of $4.50 \mathrm{pfu}$ which is close to that determined by TGA, NPD, and Mössbauer spectroscopy. To consider the likely environment for $\mathrm{Sb}^{5+}$, it is informative to explore in more detail the local environment of the $\mathrm{O} 3$ site. As shown in Table 3, each $\mathrm{O} 3$ is close to two adjacent $\mathrm{Sb}$ sites with $\mathrm{Sb}-\mathrm{O} 3$ distances of 1.91 and $2.30 \AA$. BVS considerations require an average $\mathrm{Sb}-\mathrm{O}$ distance of $1.97 \AA$ in the unoxidized phase, less than the observed value of $2.10 \AA$ (Figure $8 \mathrm{f}$ ) because the larger $\mathrm{Pb}^{2+}$ ion occupies the same site. An additional bond at $2.30 \AA$ 


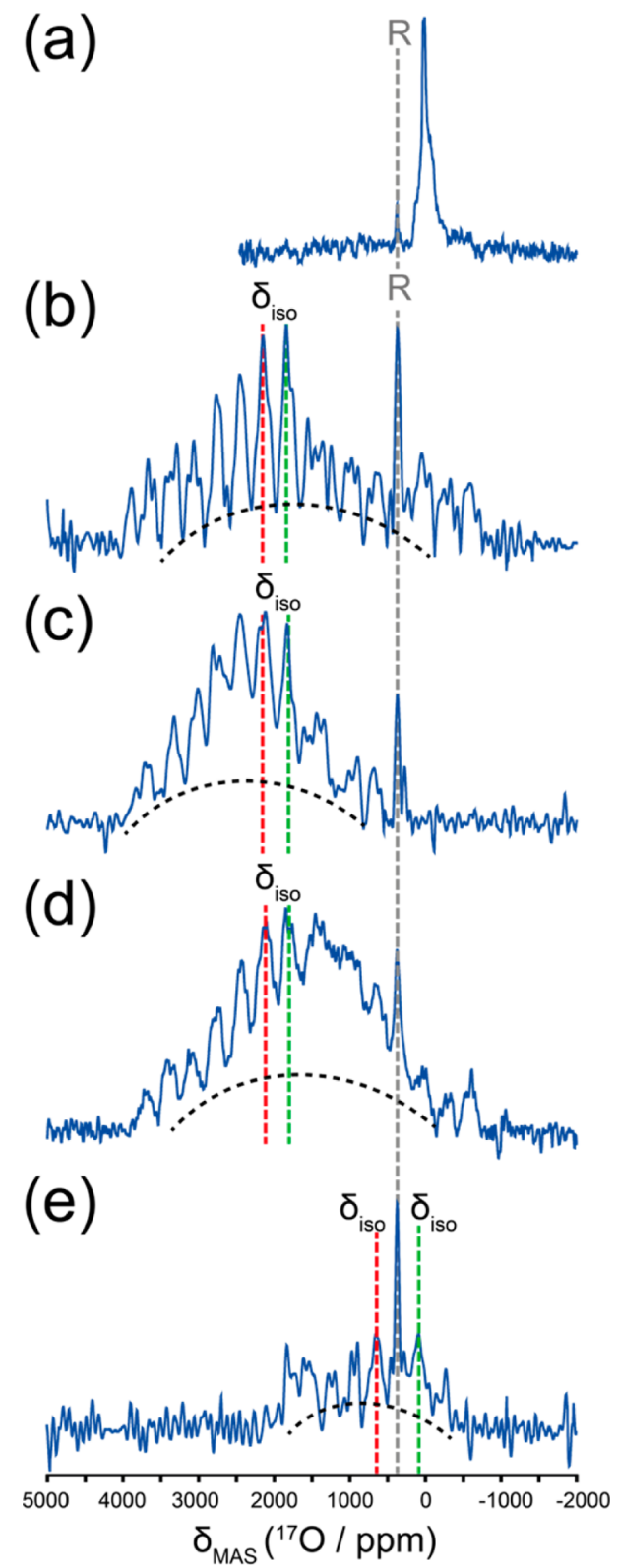

Figure 14. ${ }^{17} \mathrm{O}$ MAS NMR data $\left(\nu_{\mathrm{r}}=20 \mathrm{kHz}\right)$ from (a) diamagnetic $\mathrm{MgSb}_{2} \mathrm{O}_{4}$, (b) $\mathrm{Co}_{0.50} \mathrm{Fe}_{0.50} \mathrm{Sb}_{2} \mathrm{O}_{4+y}$, (c) $\mathrm{Co}_{0.25} \mathrm{Fe}_{0.75} \mathrm{Sb}_{1.75} \mathrm{~Pb}_{0.25} \mathrm{O}_{4+y}$ (d) $\mathrm{Mg}_{0.25} \mathrm{Fe}_{0.75} \mathrm{Sb}_{1.75} \mathrm{~Pb}_{0.25} \mathrm{O}_{4+y}$, and (e) $\mathrm{Mg}_{0.50} \mathrm{Fe}_{0.50} \mathrm{Sb}_{2} \mathrm{O}_{4+y}$. The ${ }^{17} \mathrm{O}$ signal from the $\mathrm{ZrO}_{2}$ rotor is indicated as "R" and the signal from the channel ${ }^{17} \mathrm{O}$ is represented schematically by a dashed arc.

would require an expansion of the three lattice bonds by $0.06 \AA$ to $2.03 \AA$ to retain the same BVS value. Figure $8 \mathrm{f}$ shows that this should readily be achieved and suggests that the larger $\mathrm{Sb}-$ $\mathrm{O} 3$ distance corresponds to 4-coordinate $\mathrm{Sb}^{3+}$. The bond at $1.91 \AA$, however, would require a corresponding expansion of $0.19 \AA$ to $2.16 \AA$. This appears less likely, and this bond distance is more indicative of $\mathrm{Sb}^{5+}$ : expected average $\mathrm{Sb}^{5+}-\mathrm{O}$ distances of $1.86,1.94$, and $2.01 \AA$ for coordination numbers of 4,5 , and 6 , respectively. It therefore seems highly likely that the $\mathrm{Sb}^{5+}$ ions, which we have shown to be essential to explain the observed oxygen contents, are adjacent to a 4-coordinate $\mathrm{Sb}^{3+}$ ion. The oxidation of $\mathrm{Sb}^{3+}$ to $\mathrm{Sb}^{5+}$ ion is accompanied by the introduction of an extra oxide ion into the structure; this can coordinate to the $\mathrm{Sb}^{5+}$ ion $\left(\mathrm{Sb}^{5+}-\mathrm{O}\right.$ bond distance of $1.91 \AA$ ) to provide a 5-coordinate species without a lone pair and also
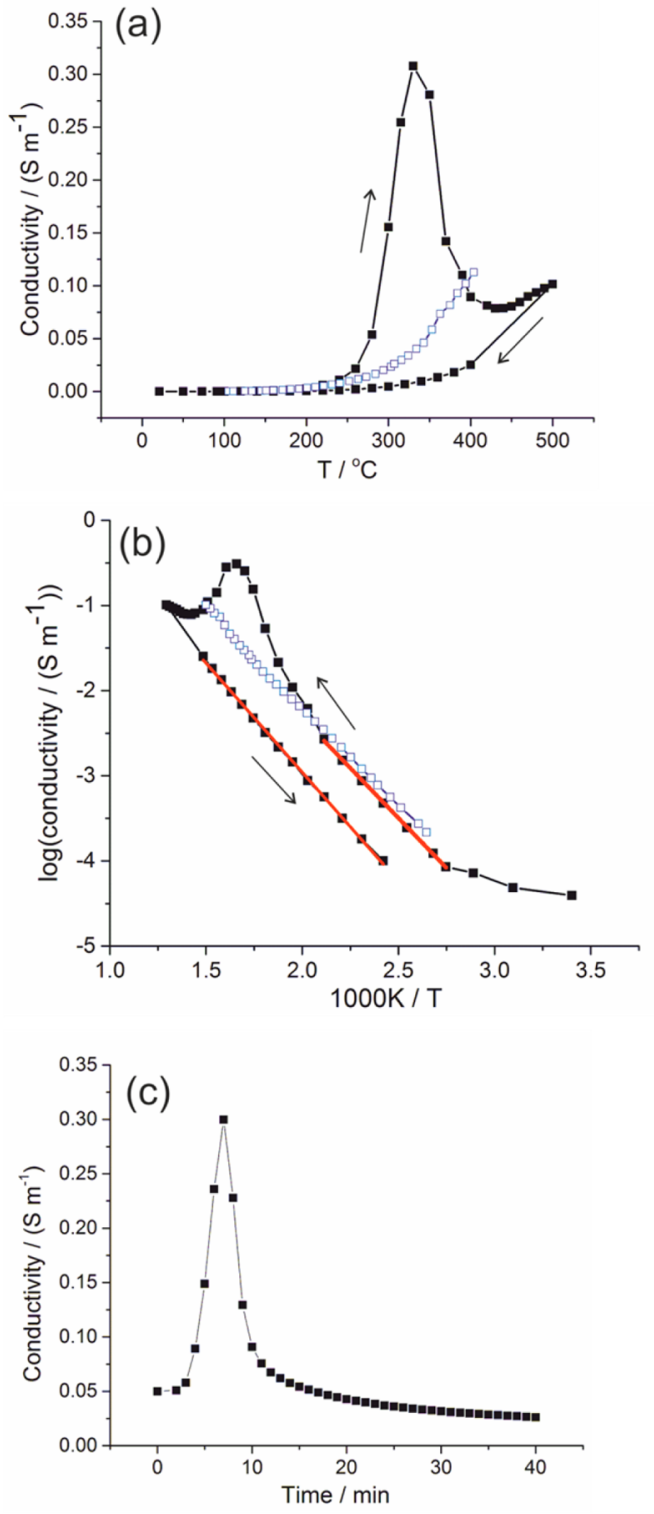

Figure 15. Electronic conductivity data for a pellet with initial composition $\mathrm{Co}_{0.50} \mathrm{Fe}_{0.50} \mathrm{Sb}_{2} \mathrm{O}_{4}$. (a) Variation of conductivity with temperature for heating and cooling in air; the blue data points are from a similar pellet heated in dry nitrogen. (b) $\log$ (conductivity) against 1000/T for the data shown in (a); the red lines are linear fits to the sections of data indicated. (c) Variation of conductivity with time at $350{ }^{\circ} \mathrm{C}$ after switching the gas from dry nitrogen to dry oxygen.

provide a link to a second 4-coordinate $\mathrm{Sb}^{3+}$ ion via a longer bond $\left(\mathrm{Sb}^{3+}-\mathrm{O}\right.$ bond distance of $\left.2.30 \AA\right)$. We therefore suggest the presence of defect clusters which contain two interstitial $\mathrm{O}^{2-}$ ions, two 4-coordinate $\mathrm{Sb}^{3+}$ ions, and one 5-coordinate $\mathrm{Sb}^{5+}$ ion. This arrangement is shown in Figure 16 and is based on the average atom coordinates given in Table 2 from the high resolution NPD data for $\mathrm{FeSb}_{1.25} \mathrm{~Pb}_{0.75} \mathrm{O}_{4+y}$. Figure 16 shows that the spatial coordination of $\mathrm{O} 3$ retains space for the lone pair on the 4-coordinate $\mathrm{Sb}^{3+}$ ion whose stereochemistry can be related to a trigonal bipyramid, $\mathrm{SbO}_{4} \mathrm{E}$, where the lone pair (E) occupies an equatorial position. $\mathrm{Sb}^{5+}$, on the other hand, is 5coordinate with a structure that can be described as either distorted square pyramidal or distorted trigonal bipyramidal. $\mathrm{Sb}^{5+}$ ions are normally octahedral in extended oxide structures, but a similar distorted geometry has previously been suggested 

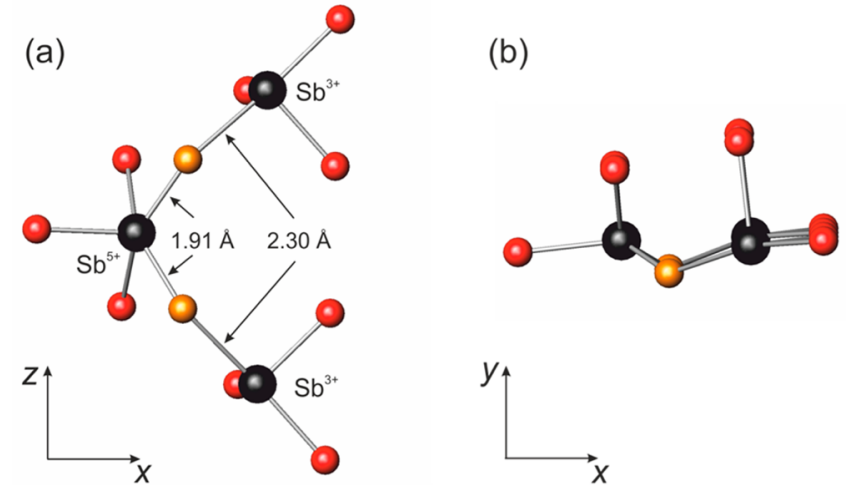

Figure 16. Proposed defect cluster comprising two 4-coordinate $\mathrm{Sb}^{3+}$ ions (black), two interstitial $\mathrm{O}^{2-}$ ions (orange), and one 5-coordinate $\mathrm{Sb}^{5+}$ ion (black) viewed (a) approximately along [010] and (b) approximately along [001]. Framework oxygen ions are shown in red and the $\mathrm{Sb}-\mathrm{O} 3$ distances are marked in (a).

in $\mathrm{Sr}_{2} \mathrm{MSbO}_{5.5}(\mathrm{M}=\mathrm{Ca}, \mathrm{Sr}, \mathrm{Ba}) .{ }^{31}$ We can use the BVS model for 3-coordinate $\mathrm{Pb}^{2+}$ ions (predicted $\mathrm{Pb}-\mathrm{O}$ bond $\left.2.262 \AA\right)^{19}$ to estimate $\mathrm{Sb}-\mathrm{O}$ distances from the average bond distances in Table 3: $\mathrm{Sb}-\mathrm{O} 1$ and $\mathrm{Sb}-\mathrm{O} 2$ are reduced to 2.016 and $1.995 \AA$, respectively. This allows calculation of the BVS values: $2.78(8)$ for 3-coordinate $\mathrm{Sb}^{3+}$ (bonded to O1, O2 [×2]), 3.19(9) for 4coordinate $\mathrm{Sb}^{3+}$ (bonded to O1, O2 [×2], O3 at $2.30 \AA$ ) and 4.73(14) for 5-coordinate $\mathrm{Sb}^{5+}$ (bonded to $\mathrm{O} 1, \mathrm{O} 2[\times 2], \mathrm{O} 3$ $[\times 2]$ at $1.91 \AA)$. The structural model shown in Figure 16 is therefore able to satisfy the bonding requirements of both $\mathrm{Sb}^{3+}$ and $\mathrm{Sb}^{5+}$

Considering the oxidation of $\mathrm{Co}_{0.25} \mathrm{Fe}_{0.75} \mathrm{Sb}_{1.75} \mathrm{~Pb}_{0.25} \mathrm{O}_{4}$ and the structural data shown in Figure 8 , the cluster discussed above can fully explain the oxidation up to $350{ }^{\circ} \mathrm{C}$, where the $\mathrm{O} 3$ site occupancy corresponds to an oxygen content of $4.5 \mathrm{pfu}$. At this point, oxidation of all the $0.50 \mathrm{Fe}^{2+}$ in the compound provides 0.25 interstitial $\mathrm{O}$, and oxidation of $0.25 \mathrm{Sb}^{3+}$ to $\mathrm{Sb}^{5+}$ contributes the same amount. This is fully supported by the Mössbauer spectra. However, it is clear from Figure 8 that oxidation continues at higher temperatures, albeit to a lesser extent. Although the structural data currently available do not allow a definitive answer to the nature of this process, it is noted that each of the 4-coordinate $\mathrm{Sb}^{3+}$ ions which terminate the cluster shown in Figure 16 could be oxidized to $\mathrm{Sb}^{5+}$ and be bonded to an additional $\mathrm{O} 3$ ion (with short $\mathrm{Sb}-\mathrm{O}$ bond) which would then create a new 4-coordinate $\mathrm{Sb}^{3+}$ ion at the end of the chain. We would expect this chain extension to cause minor changes to the existing $\mathrm{O} 3$ atoms shown in Figure 16, but these would not be apparent in the structure refinements discussed here. However, the changes seen in Figure 8 for temperatures above $350{ }^{\circ} \mathrm{C}$ are significant and indicate a change in mechanism for the oxidation process. This also manifests itself in Figure 2 where TGA data display a second plateau at temperatures above $350^{\circ} \mathrm{C}$. The Mössbauer data collected for a sample after extended heating at $500{ }^{\circ} \mathrm{C}$, Figure 12, indicate a composition that is located on this plateau.

It is acknowledged that the formation of the proposed clusters will be restricted by the random distribution of $\mathrm{Pb}^{2+}$ on the $\mathrm{Sb}^{3+}$ sites. However, statistically the effect would be small for the materials studied here. For example, for $\mathrm{Co}_{0.25} \mathrm{Fe}_{0.75} \mathrm{Sb}_{1.75} \mathrm{~Pb}_{0.25} \mathrm{O}_{4}$, bonding an inserted $\mathrm{O} 3$ ion to a given $\mathrm{Sb}$ would allow further bonding to one of two possible sites that would then become $\mathrm{Sb}^{5+}$. Each of the two sites has a
$12.5 \%$ probability of being occupied by $\mathrm{Pb}$, which corresponds to a probability of only $1.6 \%$ that they would both be occupied by $\mathrm{Pb}$. The $\mathrm{Sb}^{5+}$ can then bond to only one $\mathrm{Sb}^{3+}$ (probability $12.5 \% \mathrm{~Pb}$ ) since it can form only two bonds at $1.91 \AA$. Overall, the probability that the $\mathrm{O} 3$ ion can form the chain shown in Figure 16 is $86 \%$. Of course, as more clusters form, the probability of creating new clusters will gradually decrease.

The electronic conductivity data in Figure 15 provide a means of monitoring the oxidation of $\mathrm{Fe}^{2+}$ ions to $\mathrm{Fe}^{3+}$, since the conductivity is a maximum when the amounts of these species are equal. Unfortunately, the three-dimensional conductivity of these materials is not high, and it would be very useful to produce single crystals to allow determination of the anisotropic nature of the conductivity. It would also be interesting to synthesize and characterize materials containing some second/third row transition metal ions into the chains of octahedra in an attempt to enhance the conductivity.

The temperature at which oxidation is rapid suggests that oxygen diffusion within the channels of oxidized schafarzikite phases is high at low temperatures, but it is not straightforward to quantify this because of the electronic component and the difficulty in achieving high quality sintered ceramic samples owing to sample instability above $\sim 500{ }^{\circ} \mathrm{C}$. Further studies in this area are ongoing and will be reported separately. Nevertheless, the existence of molecular sized channels within the structural framework, and the incorporation of interstitial oxygen within them, suggests that materials with this general structure have potential as oxidation catalysts and electrocatalysts. In this respect, the wide range of transition metal cations that can be contained within the chains of octahedra could provide a means of broadening the range of catalytic potential. Examination of cations such as $\mathrm{Ru}^{4+}$ and $\mathrm{Pt}^{4+}$ would be of particular interest because of the possible enhancement to electronic conductivity. The materials studied here may also have high oxide ion conductivity, but their high relative molecular mass and toxicity are a limiting factor for their use in many energy applications.

\section{CONCLUSIONS}

This study has revealed that phases related to $\mathrm{FeSb}_{2} \mathrm{O}_{4}$ undergo a unique low temperature oxidation in air or oxygen: simultaneous oxidation of $\mathrm{Fe}^{2+}$ to $\mathrm{Fe}^{3+}$ and $\mathrm{Sb}^{3+}$ to $\mathrm{Sb}^{5+}$ occurs, and charge balance is achieved by oxide ions entering the structural channels and bonding to $\mathrm{Sb}$ in the channel walls. The resulting $\mathrm{Sb}^{5+}$ ions remain in the channel wall sites to provide a mixture of $\mathrm{Sb}^{3+}$ and $\mathrm{Sb}^{5+}$. It is not simple for the interstitial oxide ion site to satisfy the bonding requirements of both $\mathrm{Sb}^{3+}$ and $\mathrm{Sb}^{5+}$, but cluster formation achieves a stable local configuration comprising one 5-coordinate $\mathrm{Sb}^{5+}$ ion, two interstitial $\mathrm{O}^{2-}$ ions, and two 4-coordinate $\mathrm{Sb}^{3+}$ ions. Moreover, it also rationalizes all other experimental observations. At present, the electronic conductivity of schafarzikite materials is not high, but the rapid oxidation/insertion reaction that occurs at $\sim 350{ }^{\circ} \mathrm{C}$ suggests that the interstitial $\mathrm{O}^{2-}$ ions may have high mobility. Improvement of the electronic component of conductivity should provide interesting possibilities for elctrocatalyst behavior of materials with this structure, e.g. as cathodes for low temperature devices such as fuel cells and ceramic oxygen generator membranes. 


\section{ASSOCIATED CONTENT}

\section{S Supporting Information}

The Supporting Information is available free of charge on the ACS Publications website at DOI: 10.1021/acs.inorgchem.6b02466.

Full experimental details: synthesis, thermal characterization, structural characterization (PXRD, NPD; Raman, Mössbauer, and NMR spectroscopy), and conductivity measurements. XPS spectra (PDF)

\section{AUTHOR INFORMATION}

\section{Corresponding Author}

*E-mail: c.greaves@bham.ac.uk. ORCID

Colin Greaves: 0000-0002-9568-3697

\section{Notes}

The authors declare no competing financial interest.

\section{ACKNOWLEDGMENTS}

We thank EPSRC for financial support of this research (EP/ L014114/1) and EPSRC, EU and ILL for the provision of NPD facilities. We are grateful to Dr. Vladimir Pomjakushin for assistance in collecting the NPD data at PSI. We also thank Prof. Chris McConville and Dr. Marc Walker for the provision of XPS data. The X-ray diffractometers and Raman spectrometer used in this research were obtained through Birmingham Science City: Creating and Characterising Next Generation Advanced Materials (West Midlands Centre for Advanced Materials Project 1), with support from Advantage West Midlands (AWM) and part funded by the European Regional Development Fund (ERDF). We are grateful to Johnson Matthey for allowing us to use a dedicated apparatus for the exchange of ${ }^{17} \mathrm{O}$-enriched oxygen with samples heated at $350^{\circ}$ C. J.V.H. thanks the EPSRC, the University of Warwick and the Birmingham Science City Program for partial funding of the solid state NMR infrastructure at Warwick. The latter program accessed the Birmingham Science City Advanced Materials Project 1: Creating and Characterising Next Generation Advanced Materials, which derived support from Advantage West Midlands (AWM) and the European Regional Development Fund (ERDF). The UK $850 \mathrm{MHz}$ National High Field Solid State NMR Facility used in this research was funded by EPSRC and BBSRC, as well as the University of Warwick including via part funding through Birmingham Science City Advanced Materials Projects 1 and 2 supported by Advantage West Midlands (AWM) and the European Regional Development Fund (ERDF). Data associated with the results shown in this paper are accessible from the University of Birmingham Archive: http://epapers.bham.ac.uk/2226/.

\section{REFERENCES}

(1) Gonzalo, J. A.; Cox, D. E.; Shirane, G. Magnetic structure of $\mathrm{FeSb}_{2} \mathrm{O}_{4}$. Phys. Rev. 1966, 147, 415-418.

(2) Atanasova, M. T.; Strydom, A. M.; Schutte, C. J. H.; Prinsloo, L. C.; Focke, W. W. Crystal structure and magnetic properties of $\mathrm{CuSb}_{2} \mathrm{O}_{4}$. J. Mater. Sci. 2014, 49, 3497-3510.

(3) Gavarri, J. R.; Calvarin, G.; Chardon, B. $\mathrm{MeX}_{2} \mathrm{O}_{4}$ isomorphic compounds - anisotropic thermal-expansion and magnetic order in $\mathrm{MnSb}_{2} \mathrm{O}_{4}$. J. Solid State Chem. 1983, 47, 132-142.

(4) Koyama, E.; Nakai, I.; Nagashima, K. Hydrothermal synthesis of single-crystal of $\mathrm{FeSb}_{2} \mathrm{O}_{4}$ and isostructural compounds. Nippon Kagaku Kaishi 1979, 6, 793-795.
(5) Ståhl, S. The crystal structure of $\mathrm{ZnSb}_{2} \mathrm{O}_{4}$ and isomorphous compounds. Arkiv Kemi, Min. och Geol. 1943, 17B, 1-7.

(6) Tammann, G. Chemical reaction in powder form between two types of crystal. Z. Anorg. Allg. Chem. 1925, 149, 21-34.

(7) Witteveen, H. T. Magnetic susceptibility of $\mathrm{NiAs}_{2} \mathrm{O}_{4}$ and $\mathrm{NiSb}_{2} \mathrm{O}_{4}$. Solid State Commun. 1971, 9, 1313-1315.

(8) Dordevic, T.; Wittwer, A.; Jaglicic, Z.; Djerdj, I. Hydrothermal synthesis of single crystal $\mathrm{CoAs}_{2} \mathrm{O}_{4}$ and $\mathrm{NiAs}_{2} \mathrm{O}_{4}$ compounds and their magnetic properties. RSC Adv. 2015, 5, 18280-18287.

(9) Kumada, N.; Yonesaki, Y.; Takei, T.; Kinomura, N.; Wada, S. Preparation and crystal structure of a new tin titanate containing $\mathrm{Sn}^{2+}$; $\mathrm{Sn}_{2} \mathrm{TiO}_{4}$. Mater. Res. Bull. 2009, 44, 1298-1300.

(10) Ohara, S.; Takizawa, H.; Hayashi, Y. Solid-state Synthesis of $\mathrm{Sn}_{2} \mathrm{TiO}_{4}$ : A New Synthetic Strategy for Direct Synthesis of $\mathrm{Sn}^{2+}$ Compounds Using Microwave Irradiation. Chem. Lett. 2010, 39, 364365.

(11) Abakumov, A. M.; Rozova, M. G.; Antipov, E. V.; Hadermann, J.; Van Tendeloo, G.; Lobanov, M. V.; Greenblatt, M.; Croft, M.; Tsiper, E. V.; Llobet, A.; Lokshin, K. A.; Zhao, Y. S. Synthesis, cation ordering, and magnetic properties of the $\left(\mathrm{Sb}_{1-x} \mathrm{~Pb}_{x}\right)_{2}\left(\mathrm{Mn}_{1-y} \mathrm{Sb}_{y}\right) \mathrm{O}_{4}$ solid solutions with the $\mathrm{Sb}_{2} \mathrm{MnO}_{4}$-type structure. Chem. Mater. 2005, $17,1123-1134$

(12) de Laune, B. P.; Greaves, C. Structural and magnetic characterisation of $\mathrm{CoSb}_{2} \mathrm{O}_{4}$, and the substitution of $\mathrm{Pb}^{2+}$ for $\mathrm{Sb}^{3+}$. J. Solid State Chem. 2012, 187, 225-230.

(13) Whitaker, M. J.; Bayliss, R. D.; Berry, F. J.; Greaves, C. The synthesis, structure, magnetic and electrical properties of $\mathrm{FeSb}_{2-\mathrm{x}} \mathrm{Pb}_{\mathrm{x}} \mathrm{O}_{4}$. J. Mater. Chem. 2011, 21, 14523-14529.

(14) Cumby, J.; de Laune, B. P.; Greaves, C. The Structures and Magnetic Properties of $\mathrm{Fe}_{x} \mathrm{Co}_{1-x} \mathrm{Sb}_{2} \mathrm{O}_{4}$ and $\mathrm{Mn}_{x} \mathrm{Co}_{1-x} \mathrm{Sb}_{2} \mathrm{O}_{4}, 0 \leq x \leq 1$. J. Mater. Chem. C 2016, 4, 201-208.

(15) Fjellvåg, $\mathrm{H}_{\text {.; }}$ Kjekshus, A. Crystal and magnetic structure of $\mathrm{MnSb}_{2} \mathrm{O}_{4}$. Acta Chem. Scand. 1985, 39, 389-395.

(16) Caslin, K.; Kremer, R. K.; Razavi, F. S.; Schulz, A.; Munoz, A.; Pertlik, F.; Liu, J.; Whangbo, M. H.; Law, J. M. Characterization of the spin-1/2 linear-chain ferromagnet $\mathrm{CuAs}_{2} \mathrm{O}_{4}$. Phys. Rev. B: Condens. Matter Mater. Phys. 2014, 89, 014412.

(17) Minh, N. Q. Ceramic Fuel Cells. J. Am. Ceram. Soc. 1993, 76, 563-588.

(18) (a) Chroneos, A.; Yildiz, B.; Tarancon, A.; Parfitt, D.; Kilner, J. A. Oxygen diffusion in solid oxide fuel cell cathode and electrolyte materials: mechanistic insights from atomistic simulations. Energy Environ. Sci. 2011, 4, 2774-2789. (b) Kushima, A.; Parfitt, D.; Chroneos, A.; Yildiz, B.; Kilner, J. A.; Grimes, R. W. Interstitialcy diffusion of oxygen in tetragonal $\mathrm{La}_{2} \mathrm{CoO}_{4+\delta}$. Phys. Chem. Chem. Phys. 2011, 13, 2242-2249.

(19) Brown, I. D.; Altermatt, D. Bond-Valence Parameters Obtained from a Systematic Analysis of the Inorganic Crystal Structure Database. Acta Crystallogr., Sect. B: Struct. Sci. 1985, 41, 244-247.

(20) Tallman, R. L.; Margrave, J. L.; Bailey, S. W. The crystal structure of sodium peroxide. J. Am. Chem. Soc. 1957, 79, 2979-2980.

(21) Eysel, H. H.; Thym, S. Raman-spectra of peroxides. Z. Anorg. Allg. Chem. 1975, 411, 97-102.

(22) Kharbish, S. Raman spectra of minerals containing interconnected $\mathrm{As}(\mathrm{Sb}) \mathrm{O}_{3}$ pyramids: trippkeite and schafarzikite. J. Geosci. 2012, 57, 53-62.

(23) (a) Donaldson, J. D.; Kjekshus, A.; Nicholson, D. G.; Rakke, T. Properties of Sb-compounds with rutile-like structures. Acta Chem. Scand. 1975, 29, 803-809. (b) Reimers, J. N.; Greedan, J. E.; Stager, C. V.; Kremer, R. Crystal-structure and magnetism in $\mathrm{CoSb}_{2} \mathrm{O}_{6}$ and $\mathrm{CoTa}_{2} \mathrm{O}_{6}$. J. Solid State Chem. 1989, 83, 20-30.

(24) de Laune, B. P.; Berry, F. J.; Marco, J. F.; Horswell, S. L.; Greaves, C. The Structure, Chemistry and Magnetic Properties of $\mathrm{FePbBiO}_{4}$. J. Mater. Chem. C 2016, 4, 5320-5325.

(25) Ivanov, S. A.; Zavodnik, V. E. Crystal-structure of lead antimonate $\mathrm{Pb}_{2} \mathrm{Sb}_{2} \mathrm{O}_{7}$. Kristallografiya 1990, 35, 842-846.

(26) Srivastava, A.; Chauhan, M.; Padegaonker, R. Theoretical investigation of high-pressure phase transitions in $\mathrm{Mg}_{1-\mathrm{x}} \mathrm{Sr}_{\mathrm{x}} \mathrm{O}$. Phase Transitions 2014, 87, 126-135. 
(27) Svensson, C. Refinement of crystal-structure of cubic antimony trioxide, $\mathrm{Sb}_{2} \mathrm{O}_{3}$. Acta Crystallogr., Sect. B: Struct. Crystallogr. Cryst. Chem. 1975, 31, 2016-2018.

(28) Giroux-Maraine, C.; Perez, G. Crystal-structure of magnesium antimonite, $\mathrm{MgSb}_{2} \mathrm{O}_{4}$. Rev. Chim. Miner. 1975, 12, 427-432.

(29) Dupree, R.; Smith, M. E. Solid-state magnesium-25 nmrspectroscopy. J. Chem. Soc., Chem. Commun. 1988, 1483-1485.

(30) (a) McCarty, R. J.; Stebbins, J. F. Transition Metal Dopant Cation Distributions in $\mathrm{MgO}$ and $\mathrm{CaO}$ : New Inferences from Paramagnetically Shifted Resonances in O-17, Mg-25, and Ca-43 NMR Spectra. J. Phys. Chem. C 2016, 120, 11111-11120. (b) Kong, X.; Terskikh, V. V.; Khade, R. L.; Yang, L.; Rorick, A.; Zhang, Y.; He, P.; Huang, Y.; Wu, G. Solid-State O-17 NMR Spectroscopy of Paramagnetic Coordination Compounds. Angew. Chem., Int. Ed. 2015, 54, 4753-4757.

(31) King, G.; Thomas, K. J.; Llobet, A. Drastic Differences between the Local and the Average Structures of $\mathrm{Sr}_{2} \mathrm{MSbO}_{5.5}(\mathrm{M}=\mathrm{Ca}, \mathrm{Sr}, \mathrm{Ba})$ Oxygen-Deficient Double Perovskites. Inorg. Chem. 2012, 51, 1306013068 . 